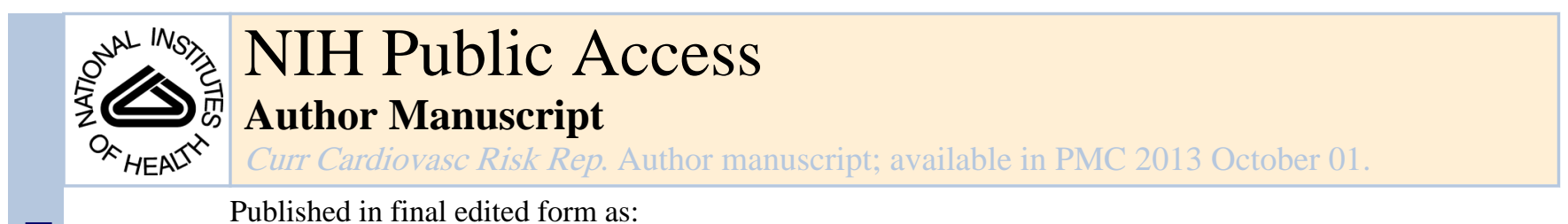

Published in final edited form as:

Curr Cardiovasc Risk Rep. 2012 October ; 6(5): 380-396. doi:10.1007/s12170-012-0260-2.

\title{
Cognition and Hemodynamics
}

\author{
Vera Novak \\ Current Cardiovascular Risk Reports
}

\begin{abstract}
The relationship between cerebral hemodynamics and cognitive performance has increasingly become recognized as a major challenge in clinical practice for older adults. Both diabetes and hypertension worsen brain perfusion and are major risk factors for cerebrovascular disease, stroke and dementia. Cerebrovascular reserve has emerged as a potential biomarker for monitoring pressure-perfusion-cognition relationships. Endothelial dysfunction and inflammation, microvascular disease, and mascrovascular disease affect cerebral hemodynamics and play an important role in pathohysiology and severity of multiple medical conditions, presenting as cognitive decline in the old age. Therefore, the identification of cerebrovascular vascular reactivity as a new therapeutic target is needed for prevention of cognitive decline late in life.
\end{abstract}

\section{Keywords}

hemodynamics; brain atrophy; cognition; aging; blood f low; hyeprtenison; hypotension; diabetes mellitus

\section{Introduction}

The relationship between cerebral hemodynamics and cognitive outcomes in aging has gained more attention because of the growing elderly population worldwide. Recently, the link between midlife cardiovascular risk factors and late-life dementia has been recognized as a potential pathway to early diagnosis of people at risk of dementia. Hypertension and diabetes are the most prevalent vascular risk factors. Hypertension affects more than a third of the world's population [1], and $16.2 \%$ people have hypotension [2]. Diabetes affects 366 million people, and this number is expected to rise to 552 millions by 2030 [3;4]. Among those who are older than 65 years, $65 \%$ to $75 \%$ have hypertension, [5] and $26 \%$ have diabetes, and these numbers are expected to rise as the global population ages.

Correspondence to: Novak, V. MD PhD, Associate Professor of Medicine, Harvard Medical School, Division of Gerontology, Beth Israel Deaconess Medical Center and Harvard Medical School, 110, Francis Street, LMOB Suite 1b, Boston, MA 02215, USA (V. Novak).vnovak@bidmc.harvard.edu, Tel: 617-632-8680, Fax: 617-667-1777.

Competing interests

The author declares no competing interests

\section{Review criteria}

This article is based on a comprehensive search of full-text English-language articles in the PubMed database, with search terms including "brain atrophy in aging," "perfusion," "cognition," "diabetes mellitus," "white matter hyperintensities, "hypotension and cognition," "blood pressure and dementia" "antihypertensive therapy" ; "endothelial dysfunction" and "angiotensine receptor" The reference lists of the articles identified during this search were checked for additional articles published from January 2005-till May 2012.

Author contributions

V. Novak contributed to discussion of content for the article, researched data to include in the manuscript, reviewed and edited the manuscript prior to submission and revised the manuscript in response to the peer-reviewers' comments.

Disclosure: No potential conflicts of interest relevant to this article were reported. 
The combination of advanced age with hypertension, diabetes and other risk factors provides a background for multifaceted interactions in pathophysiological pathways that lead to dementia. Furthermore, abnormalities in cerebral hemodynamics during midlife may contribute to late life cognitive decline. Alternative mechanisms such as genetic predisposition, inflammation, autonomic failure, and neurodegenerative changes associated with Alzheimer's disease, Parkinsonism dementia, Lewy Body dementia, or acute brain infarctions or hemorrhage may contribute to the progression of dementia.

Although the pathophysiology of the relationship between cerebral hemodynamics, cerebrovascular reserve and cognition is complicated [6], altered neurovascular coupling resulting in small vessel disease, regional hypoperfusion and neurodegeneration has emerged as one of the pathways linking cardiovascular risk factors to cognitive decline [710]. Evidence from Physiological monitoring, transcranial Doppler ultrasound (TCD) and magnetic resonance imaging (MRI) bring supports linking altered vasoreactivity to cognition. Therefore, focus on improvement of endothelial function may provide new therapeutic approaches for the prevention of cognitive decline in aging population.

\section{Brain vascular reserve}

Cerebral vasoregulation is a dynamic process that redistributes cerebral blood flow (CBF) toward the brain areas in need of increased perfusion. Vasoreactivity reflects the ability of microvasculature to adapt to a changing microenvironment, fluctuating metabolic demands such as oxygen and glucose delivery and blood pressure (BP) variations. It reflects endothelium-mediated responses at the neurovascular unit and beyond, thus regulating local, regional and global perfusions [11-13] that adjust to concomitant changes in neuronal activity and vascular tone [14]. This concept, known as neurovascular coupling, is a process in which neurons and other cells such as astrocytes and glial cells interact with endothelial cells, capillaries and blood vessels and thus facilitate the relationship among neuronal activity, hemodynamic factors, and cell-to-cell signaling [15]. These interactions allow for synchronized increases in neuronal activity and perfusion, and thus make possible communication within brain regions and functional networks.

Via neurogenic, metabolic, and myogenic regulation, neurovascular coupling enables to coordinate $\mathrm{CBF}$ redistribution to brain regions with increased metabolic demands, along with adjustments to beat-to-beat changes in transmural pressure and vasomotor tone. Neurogenic control refers to tonic and phasic activity within the central autonomic network, which includes noradrenergic, serotoninergic, cholinergic and dopaminergic signaling that modulate vasomotor tone, endothelial function and signaling among functional neuronal networks. Metabolic regulation, which is mediated by molecules such as $\mathrm{O}_{2}, \mathrm{CO}_{2}$, ATP, and glucose, among other factors, refers to the adjustment of cellular metabolisms to changes in metabolic activity and fluctuating glycemic levels, whether in tandem or in isolation.

Myogenic regulation refers to changes in endothelium-myocytes to induce contraction and relaxation of the vessel wall due to increases of intramural pressure within each heart beat.

\section{Evaluation of cerebrovascular reserve}

The ability of the neurovascular units within vascular territories and the whole brain to respond to variation in BP and intracranial pressure and to increased metabolic demands is referred to as the brain vascular reserve. Two well-described and extensively-investigated cerebral hemodynamic indices in both human and animal models are cerebrovascular reactivity to $\mathrm{CO}_{2}$, or acetazolamide, [16-19] and cerebral autoregulation, or pressure regulation [20-23] Both mechanisms compensate for changing metabolic demands and arterial pressure on account of various physiological and pathological conditions. [17;2022;24]. Several noninvasive techniques can be used to assess autoregulation and $\mathrm{CO}_{2}$ 
vasoreactivity, as well as vascular and functional responses to other stimuli, such as TCD, near infrared spectroscopy (NIRS), 3D- arterial spin labeling (3D CASL) MRI, bloodoxygen-level dependent (BOLD) MRI, 2D time of flight MR angiography, single-photon emission computed tomography (SPECT), and positron emission tomography (PET). These methods, however, reference different parameters such as blood flow or flow velocity within larger vessels, blood volume or tissue perfusion; they use different variables; and also have different temporal and spatial resolutions. Therefore, estimates of vasomotor reserve may differ greatly between these approaches.

\section{Autoregulation}

Cerebral perfusion cannot be predicted from BP alone on account of the non-linear pressureflow relationship due to autoregulation; this is in contrast to the linear or curvilinear relationship between pressure and flow in non-autoregulatory tissues. "Autoregulation" most commonly refers to CBF adaptation to acute and chronic changes in arterial BP and perfusion pressure. Pressure autoregulation maintains a fairly-stable perfusion over the range of mean systemic pressures $60-150 \mathrm{mmHg}$. Static autoregulation refers to longterm "steady-state" control, whereas dynamic autoregulation refers to the adaptation of perfusion to beat-to-beat variations in intracranial pressure and BP [25]. Many medical conditions are associated with autoregulatory impairment, such as hypertension, hypotension [26], diabetes mellitus (DM) [27], vascular disease, smoking, and stroke [28;29]. Even in healthy people, autoregulation may fail if BP falls below the lower limits during acute conditions such as syncope. With impaired autoregulation, the sigmoid autoregulation curve, which expresses the relationship between $\mathrm{CBF}$ and mean BP, becomes more linear, and perfusion becomes pressure-dependent. Figure 1 illustrates this concept.

Chronic hypertension and hypotension alter CBF autoregulation and may affect the autoregulatory range. Orthostatic and postprandial hypotension are defined as a $\geq 20 \mathrm{mmHg}$ decline in systolic BP or as a $\geq 10 \mathrm{mmHg}$ decline in diastolic BP when in an upright position, or within one hour after a meal [30]. DM is the most common cause of autonomic failure, where altered BP regulation is characterized by supine hypertension and orthostatic and/or postpradial hypotension. Therefore, the mean BP range may vary greatly from $>180 \mathrm{~mm} \mathrm{Hg}$ in supine position to $\leq 80 \mathrm{~mm} \mathrm{Hg}$ in upright position.

TCD is commonly used as a noninvasive assessment of static and dynamic autoregulation using beat-to-beat recordings of BP and blood flow velocity (BFV) [31] at baseline and during interventions such as standing up or head-up tilt [19;32]. Three patterns of autoregulatory responses were identified using a regression analysis approach in patients with autonomic failure and orthostatic hypotension; narrowed autoregulation range; normal autoregulation; and expanded autoregulation over a wide range of BP (mean BP 110-180 $\mathrm{mmHg}$ ) [26]. With normal autoregulation, regression analyses have shown no correlation between $\mathrm{BP}$ and BFV, while with expanded autoregulation BP and BFV remained highly correlated but the slope of regression line was flat. Therefore, BFV declined only mildly and was usually maintained in upright position. The autoregulation curve in hypertension was shifted to the right toward higher BP values, and therefore lower limits of autoregulation occurred at lower BP levels. With this shift, the autoregulation window narrows and the slope of the CBF-BP curve becomes steeper. In this setting, vasodilatation responses to low BP may be reduced, especially with atherosclerosis, and vasoconstriction responses to high BP may be increased, due to endothelial activation and higher sympathetic tone. In autoregulatory failure, BP and BFV are strongly correlated, marked by a steep regression slope, which results in a rapid decline in BFV even with small reductions in BP. Therefore, in an upright position BP may fall below the range of effective regulation, and perfusion decreases. As suggested by the above autoregulatory patterns, daily activities such as sitting, 
standing up, or eating a meal may reduce BFV and potentially induce hypoperfusion [33], which could lead to syncope [34], falls, or ischemia and cognitive changes [35].

Dynamic autoregulation is often assessed from spontaneous fluctuations in BP and BFV [31] at baseline and during interventions such as the Valsalva maneuver, standing up or head-up tilt. [19;32] CBF fluctuations at $0.01-0.03 \mathrm{~Hz}$ were linked with intracranial pressure [36], central sympathetic activity [37], microcirculation, and cerebral oxygenation [38]. Autoregulation is quantified using mathematical modeling, Fourier transform analysis, coherence function, and more-recently-developed nonlinear methods [22;27;39;40]. A substantial phase lead of $\mathrm{CBF}$ velocities with respect to the peripheral BP indicates intact autoregulation [31;41;42]. Nonlinear approaches, such as multiple coherence [19] and multimodal pressure-flow (MMPF), enable assessment of autoregulation at multiple time scales and have greater sensitivity and specificity to defects in autoregulation than do linear methods [27;40]. An application of the MMPF method demonstrates, for example, that hypertension and DM significantly impair autoregulation to an observable degree after an ischemic stroke [40]. Mathematical modeling has been increasingly used to assess timedependent relationships between BP, BFV and intracranial pressure and volume to predict cerebrovascular capacity and flow reserve controlled by autoregulation, perfusion pressure and cerebrospinal fluid production and reabsorption [43].

\section{$\mathrm{CO}_{2}$ vasoreactivity}

Carbon dioxide $\left(\mathrm{CO}_{2}\right)$ is a potent vasodilator stimulus that modulates vascular tone during normal breathing, slow breathing while awake and during sleep, and hyperventilation. $\mathrm{CO}_{2}$ vasoreactivity is measured from $\mathrm{CBF}$ or $\mathrm{BFV}$ responses to vasoconstrictive and vasodilatory stimuli. Examples of vasoconstrictive stimuli include hypocapnia and hyperventilation, while vasodilatory stimuli include $\mathrm{CO}_{2}$ rebreathing, breath holding, slow breathing, and acetazolamide administration [44]. Vasoreactivity is calculated as the percent flow change per $\mathrm{CO}_{2}$ change. Blood flow increases linearly over the physiological, range of the end-tidal $\mathrm{CO}_{2}$ from $25-50 \mathrm{~mm} \mathrm{Hg}$. Measurements of $\mathrm{CO}_{2}$ vasoreactivity using TCD are commonly used in clinical and ambulatory settings, because of their feasibility. Imaging technique advancements based on 3D CASL MRI [45;46] BOLD MRI, and SPECT imaging, however, enable the assessment of vasoreactivity in anatomical regions and vascular territories [47], Though these techniques present advantages over TCD by providing a better regional distribution of vasoreactivity, they lack temporal resolution and utilize values averaged over minutes.

\section{Cerebral blood flow mapping using CASL MRI}

3D CASL (CASL) enables noninvasive measurement of regional perfusion and is increasingly used to quantify perfusion and vasoreactivity $(\mathrm{mL} / 100 \mathrm{~g} / \mathrm{min})$ using established protocols and previously-described methods [48-51]. With this technique, labeling of inflowing arterial water is achieved by the application of optimized time-varying magnetic fields. The naturally-occurring hydrogen nuclei of water become the label which then decays with the MR longitudinal relaxation time T1 (approx. 1.4 seconds in blood). A labeled image is subtracted from an unlabeled image to measure CBF. Measurement of the tissuedependent $\mathrm{T} 1$ and use of established theory [52;53] permit the calculation of absolute blood flow into tissue [54]. Images are acquired with pseudo-continuous labeling, background suppression and a volumetric stack of spirals fast spin echo acquisition [48]. Cerebral blood flow maps are normalized for regional tissue volume that allows calculations of regional $\mathrm{CBF}$ and construction of vasoreactivity maps, and adjustment for regional tissue loss. The $\mathrm{CO}_{2}$ vasoreactivity is computed as the slope of the linear fit between $\mathrm{CO}_{2}$ and $\mathrm{CBF}$ values among baseline, hypocapnia and hypercapnia in each region as an absolute change, a percentage change, or both. Using this approach, vasodilation and vasoconstriction reserve 
can be calculated as absolute and relative differences from baseline [46]. Cerebral vasoreactivity differs among major vascular territories and is region-specific; it is higher in the parietal-occipital regions in comparison to the frontal and temporal regions and the insular cortex. Regions with lower vasodilatory capacity may be more affected by hypoperfusion and chronic hypoxia than those with higher capacities [45;46]. Cardiovascular risk factors such as hypertension [55], diabetes [45] and stroke [46] alter regional perfusion at baseline and also affect regional vasoreactivity in the fronto-temporal and parieto-occipital cortical regions. Typically, vasodilatation reactivity, such as the ability to augment perfusion, is reduced with diabetes, while vasoconstriction reactivity, the ability reduce perfusion, is preserved or even exaggerated [46;50]. Importantly, vasoreactivity correlates with gray matter volume and functional cognitive measures in these regions (e.g. fronto-temporal and parietal areas). In diabetic subjects, hypertension, higher systolic BP and retinopathy were further associated with lower baseline perfusion and vasodilatation reactivity.

\section{Cerebromicrovascular disease, vasoreactivity and brain atrophy}

Cerebromicrovascular disease associated with hypertension, diabetes and other cardiovascular risk factors, including age, is linked with regional hypoperfusion and brain volume loss, as well as with neuronal degeneration and cognitive decline in elderly people [56-61] Cerebromicrovascular disease accelerates age-related CBF declines [62-65] and is associated with regional differences in cerebral vasoregulation and reserve capacity [66]. Aging, hypertension, diabetes mellitus, or stroke reduce vasodilatation [45;67] in multiple vascular territories, whereas vasoconstriction can be preserved [46]. The variability of CBF responses to pathogenic stimuli underscores the importance of underlying small and large vessel disease that may lead to chronic hypoperfusion in numerous brain regions.

Measurements of CBF augmentation in response to hypercapnia using TCD [68;69] and an intravenous or inhalation ${ }^{133} \mathrm{Xe}$ method [70] suggest that cerebrovascular reserve and $\mathrm{CO}_{2}$ reactivity are impaired in persons with type $2 \mathrm{DM}$ when compared to healthy controls, and declined further with DM duration [68] and severity [66]. Hyperglycemia levels were negatively correlated with $\mathrm{CO}_{2}$ reactivity and response to phenylephrine infusion-induced BP elevations [69]. Improper DM control with hemoglobin A1c (HbA1c) $>10 \%$ was associated with more severe albuminuria, acute hyperglycemia, higher von Willebrand factor activity, and marginally-higher neuropathic scores, but it was not associated with changes in global cerebrovascular reactivity. These findings suggest that cerebrovascular reserve impairment may be regional and conditional on structural changes of resistance arteries or metabolic factors [71] in specific brain regions. A higher pulsatility index also indicates an increased intracranial vascular resistance and microvascular damage in DM [72].

Recent advances in ultra-high-field MR has allowed unprecedented resolution and enabled the visualization of microvascular diseases such as lacunar infarctions, microinfarctions, microbleeds, iron deposits, and diffused white matter hyperintensities (WMHs) with unprecedented resolution [73-76]. Figure 2 demonstrates small vessel disease and aptterns of abnormal microvascularture that occur with hypertension.

Microinfarcts and iron deposits in brain tissue associated with altered blood brain barrier BBB in patients with hypertension were previously invisible in lower-resolution scans [75;77]. WMHs common in MRIs of older adults are often associated with global and regional brain atrophy, including hippocampal atrophy [64]; reduced functional neuronal mass, which indicates that an active neurodegenerative process has taken place [78]; lower perfusion [79] and metabolism in the white matter, preferentially affecting frontal, parietal, and temporal cortices [80]; lower oxygenation in the frontal lobes [81]; slower CBF 
velocities [82]; cognitive decline and executive dysfunction [83]; vascular dementia [8486]; motor impairment [87]; and depression [88]. The presence of WMHs at baseline was also associated with an increase in diastolic BP over 24 years of the follow-up ( $>10 \mathrm{mmHg}$; OR 2.6, 95\% CI 1.3-5.1), systolic BP (>40 mmHg; OR 2.0, 95\% CI 1.2-3.4), pulse pressure (>24 mmHg; OR 1.8, 95\% CI 1.1-2.7), and mean arterial pressure (>6 mmHg; OR $2.2,95 \%$ CI 1.4-3.4) [89].

The pathogenesis of multifocal, as well as, diffuse WMHs in older adults, however, remains unclear [90]. Histopathology of deep periventricular WMHs is heterogeneous, showing partial loss of myelin and axons, astrogliosis, dilatation of perivascular spaces, activated macrophages and fibrohyalinosis [91;92]. Punctuate and diffuse lesions in deep white matter are associated with arteriolosclerotic changes and with incomplete and complete infarctions [93]. In addition, microvascular disease and subcortical WMHs were associated crosssectionally with cognitive impairment, [58-60] and longitudinally with the rate of cognitive decline [60] among community-dwelling elderly. The strong association of WMHs with diabetes and hypertension [60;94] supports the hypothesis of BBB break down [95]. A subsequent demyelination of white matter may occur independently of perivascular inflammation in the gray matter.

Subcortical WMHs have been associated with cognitive impairment at baseline $[59 ; 60 ; 86]$ and also longitudinally with the rate of cognitive decline [60]. Older people with large subcortical WMHs have higher systolic BP, reduced cerebral metabolism, and worsened cognitive performance [96;97]. This evidence further suggests that the multifactorial pathways leading to WMHs also affect perfusion in the gray matter and white matter, and converge on neuronal death, cortical and subcortical white matter disconnection, and that this process can precede functional decline for many years, The associative areas of the frontal and temporal cortices and limbic circuits, which are involved in complex tasks, such as, decision-making, and memory, that have high demands on perfusion and energy supply are preferentially affected by neuronal death [98]. Other mechanisms and genetic predisposition (such the $A p o E \varepsilon 4$ genotype), however, are also involved and may further alter blood flow regulation and contribute to WMHs, deposition of amyloid $\beta$ A4 protein and neurofibrillary tangles, altered cholinergic transmission. The interplay among these mechanisms is complex and poorly understood. For example, clearance of amyloid $\beta$ A4 protein from the brain is dependent on vascular reactivity, which in turn is affected by small vessel disease. Therefore, DM and hypertension and other conditions associated with small vessel disease may contribute to the pathology of Alzheimer's disease [99-103]. Recently, it was shown that the vascular defects in APOE-deficient and ApoE4-expressing mice precede neuronal dysfunction and may initiate neurodegenerative changes. Astrocyte -secreted $A p o \mathrm{E} 3$, but not $A p o \mathrm{E} 4$, suppressed the CypA-nuclear factor- $\mathrm{BB}$-matrix-metalloproteinase-9 pathways in pericytes through lipoprotein receptors, resulting in blood-brain barrier BBB breakdown, and initiation neuronal cell death. More studies are needed to determine whether these results translate into neurodegeneration in humans [104].

\section{Endothelial dysfunction, inflammation and vasoreactivity}

Age-related endothelial dysfunction and risk factors such as hypertension and DM set the stage for altered neurovascular coupling and regional decline in vasomotor capacity [66]. Endothelial dysfunction is associated with vascular inflammation due to glucotoxicity, lipotoxicity and neurotoxicity affecting neurons, astrocytes and endothelial cells.

Microangiopathy alters vessel permeability [105;106] and vasoreactivity [69], but its severity may differ between peripheral and cerebral circulation, as well as between organ systems. With DM, adaptive neovascularization such as capillary density, arteriogenesis and intratree anastomoses is diminished in the peripheral circulation, contributing to cardiac and renal diseases [107]. In contrast, neovascularization in the brain may be augmented yet still 
dysfunctional [107]. This condition manifests as an increased media-lumen ratio, a compromised BBB and increased activity of matrix mattaloproteinases (MMP) [108]. Therefore, inflammation- activated microglial cells and invading macrophages play important roles in altered neurovascular coupling, BBB permeability and, ultimately, neuronal loss. The combined effects of cardiovascular risk factors induce oxidative stress in mitochondria [109;110] and the endoplasmic reticulum, which triggers the release of proinflammatory cytokines and activation of pro-apoptotic pathways [111]. This cascade leads to endothelial dysfunction, decreased synthesis of nitric oxide and sympathetic activation [111], and culminates in a decline in vasodilatory reactivity [12]. Vasoconstriction responses may be exaggerated through the activation of sympathetic vasomotor fibers and endothelin-1 pathways [111]. Adhesion molecules are concomitant with altered endothelial cell motility through nitric oxide dependent pathways [112;113], angiogenic activity and neovascularization [114]. The regional effects of hyperglycemia on neurovascular coupling, metabolism, and neuronal function are dependent on energy demands [115-117] Therefore, cognitive and motor regions with high metabolic rates [118;119] are particularly vulnerable to hyperglycemia and vascular inflammation [120;121]. Recently, it has been shown that serum intercellular adhesion molecules [ICAM] and vascular cell adhesion molecules [VCAM] are associated with altered vasoreactivity and gray matter atrophy in several brain regions in older diabetic but also in non-diabetic hypertensive adults [50], and that cell adhesion molecules were also associated with worsened cognition. Notably, gray matter brain volume loss was not related to other cytokines such as tumor necrosis factor alpha [TNFa], C-reactive protein [CRP], endothelin-1, or interleukins 1-6 [IL1-6], which suggests that CAMs may serve as new serum markers of endothelial dysfunction in the brain [50]. The relationship between adhesion molecules, impaired vasoreactivity and atrophy may indicate an ongoing inflammation-remodeling process of activated endothelium, marking degeneration and angiogenesis in the affected cortical regions. Thus, in the presence of DM and other cardiovascular risk factors (e.g. obesity, hypertension, hypercholesterolemia, and metabolic syndrome), increased oxidative stress and inflammation may lower the intrinsic threshold for cell survival [122] and accelerate aging and atrophy in the affected regions.

\section{Midlife risk factors and cognitive decline in old age}

The actual relationship between age and cognition in senescence, however, might be predictable over the course of a lifespan if neurovascular coupling is considered a variable acting on cerebral vasoregulation in response to BP and metabolic factors. Mounting evidence suggests that the association of endothelial dysfunction, microvascular disease, and mascrovascular disease may have an important role in the manifestation and severity of multiple medical conditions underlying cognitive decline late in life. Figure 3 illustrates the conceptual model of pathways by which cardiovascular risk factors (hypertension, obesity, diabetes) may alter brain perfusion and ultimately lead to brain atrophy and functional decline.

The size of the aging population is increasing exponentially, while the obesity and diabetes epidemics are still on the rise. Cognitive decline, slow gait speed, and falls are all common manifestations of the subcortical frontal dysfunction that occurs frequently with aging. There is growing evidence that DM accelerates the aging process in the brain [103;123125]. There is also increasing evidence for the relationship between BP pressure regulation through the lifespan and cognitive deterioration and dementia later in life [126-131]. Diabetes and BP dysregulation have been linked not only with Alzheimer's disease pathophysiology and vascular dementia, first and second most common types of dementia but also with mild cognitive impairment (MCI). The involvement of vascular mechanisms such as strokes, lacunar infarcts, small vessel disease, and cardiovascular diseases in vascular dementia underscores the importance of altered neurovascular coupling in these 
pathologies. [132] A diagnosis of MCI is distinct from that of dementia. A person diagnosed with MCI has abnormal cognitive function with objective and subjective markers of cognitive deterioration, although there may be minimal to no impact on the complex functions of daily living. Impaired [133;134].

Older adults have shown distinct patterns of decline in verbal fluency and figural recognition. Better performance is associated with greater regional CBF in the inferior temporal gyrus and inferior parietal lobe [135-137] However, CBF in these regions declines with age, and individuals with a steeper decline had worse cognitive performance. A positive association between CBF and motor performance was also seen in the sensorymotor regions in the pre- and postcentral gyrus. Participants with faster reaction times had better CBF in the parahippocampal region and hippocampus. Faster performance on the figural task was related to greater $\mathrm{CBF}$ in the insula and decreased $\mathrm{CBF}$ in the middle frontal gyrus, while slower performance on this task was associated with decreased CBF in the superior and middle temporal gyri, regions associated with visuospatial processing [135137]. The Framingham Heart Study group cardiovascular disease risk profile score (FCRP) was used to prospectively assess the relationship between baseline cardiovascular risk and subsequent changes in resting state $\mathrm{CBF}$ and brain tissue volumes over the 8-year follow-up in 97 cognitively-normal older participants from the Baltimore Longitudinal Study of Aging [135-137]. Voxel-based changes in regional CBF, measured by resting PET and MRI scans, were correlated over time with cognitive outcomes such as a verbal fluency test and FCRP composite score, as well as its individual components age, cholesterol, BP, smoking status, and type $2 \mathrm{DM}$. Higher baseline FCRP scores were associated with faster decline in regional CBF in the orbitofrontal, medial frontal andanterior cingulate, insular, precuneus, and brain stem regions. Specifically, higher diastolic BP and DM are independently associated with greater CBF decline in the medial frontal, anterior cingulate and insular regions. DM and higher vascular resistance are associated with faster cognitive decline.

Epidemiological studies and clinical trials suggest that risk factors in mid-life, such asobesity, DM and hypertension, increase the risk of cognitive deteterioration in old age. Central pattern of abdominal obesity is a major risk factor for type $2 \mathrm{DM}$. A prospective study of adults 40-69 years old with a 12-year follow-up showed that the most severe central obesity, and hypertension were each related to poorer performance on tests of executive function and visuomotor skills like the Trail-Making Test Part B and visual reproduction and recall tests [138]. Obesity correlated with increased cerebrovascular resistance, particularly in the upright position, slowed CBF velocities, increased systolic BP, and male gender. [139] In the ARIC study, hypertension and DM are associated with a decline in executive function tasks such as verbal learning, recall and fluency, and digit symbol recognition [140]. In the NHANES III study, stroke and the ApoE4 genotype were independent predictors of verbal memory decline as assessed by the Delayed Word Recall Test. For the Word Fluency Test, metabolic syndrome, hypertension, and stroke were each independently associated with cognitive decline [141]. The Honolulu Aging study shows that high systolic BP $(120-140$ and $\geq 140 \mathrm{mmHg})$ in midlife increases the risk of late-life dementia. Men who developed dementia had an additional age-adjusted increase in systolic BP of $0.26 \mathrm{mmHg}$ (95\% CI $0.01-0.51 \mathrm{mmHg}$ ) from midlife to later life. Up to $58 \%$ of those with dementia experienced a systolic BP decrease of $\geq 10 \mathrm{mmHg}$ in later life [142]. The risk ratio for dementia was lower in patients treated for hypertension than in untreated patients $(\mathrm{RR}=0.76,95 \% \mathrm{CI} 0.65-0.93$ and $\mathrm{RR}=1.05,95 \%$ CI 0.86-1.27, respectively $)$ [143]. In hypertensives, decreased CBF measured by PET was associated with a decline in Mini Mental State Examination (MMSE) scores over the 3-years of follow up [144].

The relationship between low perfusion and dementia later in life was suspected. The SMART-MR study has shown that cerebral hypoperfusion is among the mechanisms 
contributing to dementia $\left[84 ; 145^{*}\right]$. This study measured CBF using MRI and angiography in 575 patients with atherosclerotic disease. Baseline parenchymal CBF declined from $52.3 \pm 9.8$ to $50.7 \pm 10.3(\mathrm{ml} / \mathrm{min} / 100 \mathrm{ml})$ after $3-6$ years of the follow up. Regression analyses adjusted for age, sex, follow-up time and vascular risk showed that untreated and poorlycontrolled hypertension and higher levels of systolic and diastolic BP were associated with CBF decrease. However, within hypertensive patients $(n=469)$, those patients treated with angiotensin receptor blockers (ARBs) did not show CBF decrease as compared to participants using other antihypertensive medications. Type $2 \mathrm{DM}$ is associated with cortical and subcortical atrophy, lacunar infarcts and asymptomatic infarcts [146;147]. Cortical and subcortical atrophy itself is linked with the duration of diabetes and $\mathrm{HbA1c}$ and with impaired attention and executive functions, processing speed, and memory.

Figure 4 demonstrates that an older diabetic person has more global and regional atrophy on MR images as compared to non-dabetic adult.

Cortical and subcortical atrophy itself is linked with the duration of diabetes and $\mathrm{HbAlc}$ and with impaired attention and executive functions, processing speed, and memory. Cognitive performance is inversely related to atrophy, WMHs and silent infarcts. There is also a moderate relationship among cognitive decline, HbA1c, and DM duration. [61] The population-based Kunsgholmen study reported that DM was associated with hazard ratios of 1.5 for dementia, 2.6 (95\% CI 1.2 to 6.1) for vascular dementia, and 1.3 for Alzheimer's disease. In patients who were treated with oral antidiabetic medications, the hazard ratio increased to 1.7 (95\% CI 1.0 to 2.8) for dementia and to 3.6 (CI 1.3 to 9.5) for vascular dementia. The risk for vascular dementia increased further in DM patients with severe systolic hypertension or heart disease [85]. Most studies suggest that patients with subcortical vascular dementia are more impaired on frontal-executive tasks than memory, such as free recall, but recognition or cued memory is often well-preserved. [148] Therefore, chronic hyperglycemia may worsen age-related vascular dysfunction, thereby leading to early degeneration of associative brain regions with higher metabolic demands involved in cognition or motor control. Increasing evidence shows that subcortical WM degeneration may contribute to slow gait speed, psychomotor slowing, and poor balance in older people even in the absence of peripheral neuropathy. In a study of more than 700 communitydwelling participants from the Cardiovascular Health Study, WMHs were associated with poorer performance on tests of balance using both clinical and dynamic posturography measures [149]. Among 1077 non-demented elderly men and women participating in the Rotterdam Scan Study, [60] those with the most severe diffuse subcortical WMHs scored nearly 1 SD below the mean on tests of psychomotor speed. Whitman et al. [150] demonstrated that the progression of WMHs is associated with falls and poor postural control. Because of the close proximity of frontal-subcortical circuits that control both motor and cognitive functions, it is not surprising that periventricular vascular lesions may cause simultaneous dysfunction in both systems.

Uncontrolled diabetes is associated with adverse effects due to hyperglycemia, small vessel disease, and hypoperfusion of vital organs. Surprisingly, the effects of improved glucose control on coronary and cerebrovascular complications in this population are debated. The optimal range for glycemic control in vulnerable older patients is still not known, and the target $\mathrm{HbA} 1 \mathrm{c}$ levels remain debated. Three randomized control trials (ACCORD, ADVANCE, Veterans Affairs Diabetes) have assessed the impact of intensive glucoselowering therapy on cardiovascular complications and mortality. [151-153] None of these studies were able to demonstrate significant reduction of cardiovascular events or strokes in the intensive therapy group as compared with the control group. The ACCORD trial enrolled 10,251 participants, with primary intensive glucose lowering therapy with embedded lipid and blood pressure controls $\mathrm{HbA1c}<6.0 \%$ vs. 7.0-7.9\%, primary outcomes 
(nonfatal myocardial infarction, stroke, and cardiovascular death) [154]. A subset study of this population, Memory in Diabetes (ACCORD-MIND), assessed the primary outcome Digit Symbol Substitution Test (DSST) score, at baseline and at 20 and 40 months after treatment [143]. There was no significant treatment difference in mean 40-month DSST score. The intensive-treatment group had a greater mean total brain volume than the standard-treatment group, but cognitive outcomes were not different. Therefore, these findings do not support the use of intensive glucose lowering therapy for reduction of adverse effects of diabetes on the brain.

\section{Regional atrophy and hypoperfusion in diabetes mellitus, hypertension and hypotension}

Previous studies have shown cross-sectionally that regional perfusion in the frontal and temporal lobes and other areas with higher metabolic rates are specifically affected by diabetes [118]. CBF abnormalities were most frequently seen in the fronto-temporal region, followed by the occipital and parietal regions [155], and were more frequent in long-term DM. Hypoperfusion was also related to fluctuating blood glucose and HbA1c levels and to the frequency of hypoglycemia [66;69]. In diabetics, the ratio between regions with normal $\mathrm{CBF}$ compared to reduced CBF was lower than in the controls and inversely correlated with systolic BP, total cholesterol, and atherogenic index. These observations suggest that the combination of hyperglycemia with other risk factors for atherosclerosis may accelerate agerelated decline in perfusion $[119 ; 156]$. During hypoglycemia, CBF increased to areas associated with higher metabolic rate, such as the superior frontal cortices and the right thalamus, and decreased to the right posterior cingulate cortex and the right putamen [157;158]. Type $2 \mathrm{DM}$ is associated cross-sectionally with modest cortical and subcortical atrophy, lacunar infarcts and asymptomatic infarcts [86;146;147]. Cortical and subcortical atrophy was linked with diabetes duration and HbAlc and with impaired attention and executive functions, processing speed and memory. In particular, gray matter loss was greater in areas used for memory and language processing, such as the superior temporal and angular gyri. Poorer cognitive performance was associated with more atrophy, WMHs and silent infarcts [61]. Gray matter density declined with elevated lifetime HbA1c levels, DM duration, and diabetic retinopathy. It appears that superior temporal gyri may be particularly vulnerable to diabetes, as suggested by the relationship between HbA1c and atrophy in these regions [159].

Hypoglycemia-Intensive glycemic control increases the risk of hypoglycemic episodes, which may also lead to cerebral hypoperfusion, dysautonomia and unawareness of subsequent episodes. During hypoglycemia CBF is increased to areas associated with higher metabolic rate and cognitive and motor processing, such as the superior frontal cortices and the right thalamus, and it is decreased to the right posterior cingulate cortex and the right putamen. [157;158] The reasons for variability in regional CBF responses to hypoglycemia are not well known. More severe hypoglycemia may trigger sympathetic activation, which may in turnlead to cerebral vasoconstriction and hypoperfusion and loss of consciousness. [160] These observations suggest that the combination of hyperglycemia with other risk factors for atherosclerosis may accelerate age-related decline in perfusion. [119;156]

Hypotension-The relationship among BP regulation, autonomic failure and dementia later in life is debated. With orthostatic hypotension, cerebral perfusion depends on autoregulation to maintain perfusion at lower BP levels. Among patients with low BP, (systolic BP $<120 \mathrm{mmHg}$, diastolic $\mathrm{BP}<70 \mathrm{mmHg}$ ), orthostatic hypotension increased the odds of cognitive impairment (measured as $>1$ MMSE score decline) [161]. This effect mey ba due to a decreased cerebral perfusion, whne BP falls below an autoreuglated range. In contrast, among patients with hypertension (systolic BP >140 $\mathrm{mmHg}$, diastolic $\mathrm{BP}>90$ $\mathrm{mmHg}$ ), the presence of orthostatic hypotension reduced the odds of cognitive impairment 
$(\mathrm{OR}=0.48,95 \%$ CI $0.26-0.90)$ [162]. This effect may be due to decreased cerebral vasoconstriction, when BP decline to an autoregulated range. In patients with chronic cerebral infarctions, BFVs decline during daily activities such as sitting, standing or a passive head-up tilt, and that these activities may induce recurrent hypoperfusion. [163] Lower perfusion correlates with worse post-stroke outcomes. Therefore, stroke patients may need a higher perfusion pressure to maintain blood flow during daily activities [46]. Lower perfusion also correlates with worsened outcomes in non-stroke diabetic patients [45]. Analogously, diabetic patients may need to maintain glucose and BP levels within a certain range to maintain perfusion and respond adequately to metabolic demands.

The Malmö Preventive Project [164] assessed the relationship between orthostatic hypotension and long-term morbidity in 722 men aged $52.6 \pm 3.6$ years over a follow-up of $19 \pm 5.3$ years. Orthostatic hypotension was observed in $9.9 \%$ of participants and was independently associated with age, low BMI, hypertension, increased heart rate, antihypertensive treatment, DM, and current smoking. Systolic hypotension was observed in $64.5 \%$ of those with hypotension, and was associated with high pulse pressure, and reduced glomerular filtration rate. Men with orthostatic hypotension had an increased risk of coronary events, stroke and all-cause mortality. Those with orthostatic hypotension, both at baseline and at screening during follow-up were at the highest risk of any adverse event. Similarly, hypotension was associated with low MMSE scores $(<24)$ in The Helsinki Aging Study [165], which involved 650 people aged $75-85$ years.

Furthermore, frailty was also associated with an inability to regulate orthostatic BP and with lower orthostatic heart rate and BP. On average, after 30 seconds of standing, non-frail subjects had recovered $98 \%$ of their baseline systolic BP, while pre-frail and frail subjects had recovered 95 and 92\%, respectively [166]. The prevalence of Alzheimer's disease is higher among people with systolic $\mathrm{BP}<130 \mathrm{mmHg}$ and diastolic $\mathrm{BP}<70 \mathrm{~mm} \mathrm{Hg}$, as compared to the reference group (systolic BP 130-139 mm Hg) [56;167] The OPTIMA study [124] prospectively evaluated cognitive function using The Cambridge Cognitive Examination (CAMCOG) tool in 235 cognitively healthy participants, 42 with MCI, 141 with Alzheimer disease, and 59 with other dementia syndrome. In patients with Alzheimer disease, the decline in cognitive scores showed a nonlinear, inverted U-shaped dependence on diastolic BP. Both low and high diastolic BP levels $(<60 \mathrm{mmHg}$ and $>110 \mathrm{mmHg}$ ) were related to faster cognitive decline over 5 years of follow-up $(\mathrm{z}=-2.51, P=0.012)$. These studies suggest that the combination of altered vasoregulation and declining BP later in life may indicate underlying autonomic failure associated with DM, Alzheimer's disease, Parkinsonism dementia, Lewy Body dementia and other disorders. The loss of central regulation of perfusion and autonomic peripheral BP controls may have a broad impact on brain cognitive networks and, ultimately, on morbidity and mortality. The link between these factors, however, remains to be further studied.

\section{Antihypertensive therapy and cognition}

The inconsistencies in these trials, evident in both individual studies and meta-analyses, are likely related to differences in the populations studied, including variation in age and in baseline cognitive function. The cognitive domain of interest and method of assessment in the studies are additional important explanations for this heterogeneity. Many of the trials have used MMSE, a fairly-insensitive and nonspecific measure of cognitive change [168], but hypertension is more likely to be related to executive function than to the overall cognitive performance that the MMSE assesses [169-171]. Pharmacogenetic variation in cognitive responses, study duration, and pharmacokinetic characteristics of antihypertenives are additional factors that lead to heterogeneity in studies of hypertension therapy and cognitive function. A meta-analysis of randomized controlled trials of antihypertensive 
therapy in the elderly indicated that BP reduction lowers the risk of stroke (35\%), cardiovascular events (27\%) and heart failure (50\%), but it does not affect mortality [172]. By contrast, smaller BP reductions and lower intensity of therapy were associated with decreased mortality. The US Veteran Affairs prospective study [173] determined that ARBs are more effective in lowering the risk of Alzheimer's disease and dementia compared with the angiotensin-converting-enzyme (ACE) inhibitor lisinopril or other classes of cardiovascular medications. Other trials that assessed the use of ARBs on cognitive function demonstrated a superior effect of this class of drugs (e.g. candesartan, losartan, valsartan) in comparison with the $\beta$-blocker atenolol [174] and a combination hydrochlorothiazide and lisinopril [175].

Antihypertensive drugs such as ACE inhibitors like perindopril, and captopril, ARBs such as losartan $[174 ; 176]$ and calcium-channel blockers like nitrendipine may have class-specific effects, and combination therapy might have an increased cognitive protective effect. For example, in the Cardiovascular Health Study, ACE inhibitors that cross the blood-brain barrier provide cognitive protection, which is not observed with ACE inhibitors that do not cross the blood-brain barrier [177]. Even though these studies may differ a common thread emerges; namely, that antihypertensive treatment is protective against vascular diseases and some of their consequences in the brain. The target for BP lowering that would be protective against cognitive decline remains to be determined.

\section{Central benefits of renin-angiotensine receptor blockade}

Evidence from clinical studies suggests that treatment of hypertension using reninangiotensin receptor blockers may have beneficial effects on endothelial function, and vasoreactivity that go beyond the lowering of BP. The brain renin-angiotensin system regulates systemic responses to chronic stress induced by hyperglycemia, such as sympathetic activation, vasoconstriction, and neuroinflammation. AT1 receptors are abundant in the brain and are located on endothelial cells as well as on the inner side of the BBB [178]. Binding of angiotensin II to AT1 receptors mediates key events in neuroinflammation and neurodegeneration [179]. An important relationship between AT1 receptors and BBB endothelial cells' permeability [180] and ICAM has been reported. Angiotensin II increases vascular permeability by promoting the expression and secretion of vascular endothelial growth factor [181] and induces the expression of endothelial adhesion molecules like cellular adhesion moelcules and selectins, thus promoting leukocyte adhesion in arteriolar endothelium [182]. Stimulation of AT1 receptors mediates cell proliferation, fibrosis, vasoconstriction, aldosterone release, and inflammatory response [183]. However, the differences in nitric oxide (NO)-mediated endothelial dysfunction between peripheral macrocirculation and microcirculation and regional cerebral circulation remain unclear.

The AT1 receptor blockade improves cerebrovascular compliance associated with hypertension and inhibits oxidative stress, pathological cerebrovascular remodeling and inflammation [184-186]. That ARB treatment improves BBB permeability suggests the RAS system is also involved in the pathophysiology of endothelial dysfunction and subsequent damage to neural tissue [187]. Systemic ARB treatment inhibits central hypertensive effects, vasopressin secretion, and the drinking response in spontaneously hypertensive rats [188]. AT1 receptors located in the neurovascular unit [180;189] most likely mediate the central effects of ARBs. Candesartan can cross the BBB, down-regulate the central renin-angiotensin system [190], and decrease angiotensinogen and angiotensin converting enzyme mRNA levels in brain tissue [190]. Both losartan and ACE inhibitor enalapril restore vasoreactivity after BBB injury [191;192].

ARBs are well-tolerated and extensively used to treat cardiovascular and metabolic disorders such as hypertension and diabetes, in which inflammation is an integral pathogenic 
mechanism, and may have broad benefist for vascular fucniton that are independent of their BP lowring effects. Furthermore, ARB treatment benefits extend beyond BP reduction. Treatment with AT1 receptor antagonists appears to be a major therapeutic avenue for the prevention of small vessel disease and inflammation in the brain [184;186;193].

Major clinical trials have demonstrated that ARBs increase insulin sensitivity and reduce the incidence of DM, independent of their BP effects [184;186;194;195]. In clinical trials, treatment with ARBs improved vascular function and atherosclerosis associated with diabetes [196-198]. In the Losartan Intervention For Endpoint (LIFE) reduction in hypertension study and the Study on Cognition and Prognosis in the Elderly (SCOPE), [199] treatment with ARBs was associated with reduced occurrence of stroke compared to controls, without significant change in all-cause mortality and with decreased new onset of diabetes (RRR 0.80, 95\% CI: 0.74-0.86, p < 0.00000001) [200]. Treatment with ARBs reduced cognitive decline as measured by the MMSE [199]. In the On TARGET trial of 28,384 participants, ARBs reduced MMSE decline in people with baseline macroalbuminuria [197]. ARBs also decreased depressive symptoms, [201;202] possibly because brain inflammation plays an important role in the pathophysiology of mood disorders [203;204].

Valsartan many beneficial effects on both peripheral circulation and the brain, by means of its broad anti-inflammatory actions; these effects are independent of BP reducton. In animal studies, valsartan had vascular and neuroprotective effects such as prevention of proteinuria, preservation of renal structure, delayed appearance of brain damage, increased survival under stressful conditions, [205;206] and ameliorated cognitive impairment in diabetic rats [189]. Valsartan has shown beneficial effects on insulin sensitivity, [200] inflammation, [207] vascular reactivity, [208] and cognitive and executive function [209] at the dose of $160 \mathrm{mg}$ once daily (o.d.). Valsartan treatment lowered the incidence of DM in elderly hypertensives (VALUE trial) [200;210-212]. A reduction of inflammation as measured by ICAM and high-sensitivity C-reactive protein was observed after 6 weeks of valsartan treatment (VAL-MARC), [207] but not after treatment with the ACE inhibitor trandorapril [213]. Therefore, the evidence supporting the use of ARBs for treatment of inflammation and endothelial dysfunction in the brain of older diabetic adults is compelling.

\section{Conclusions}

Substantial evidence exists that supports a link between cerebral perfusion and cognition, a relationship that may be mediated by impairment of vascular reserve and microvascular disease. Not only do cardiovascular risk factors exert long-term effects on vascular function and perfusion regulation that may accelerate later functional cognitive loss, but they also directly contribute to brain atrophy and cognitive decline when combined with conditions such as diabetes, hypertension and hypotension.

Enhanced understanding of the effects of cerebral hemodynamics on cognitive performance, can inform the development of effective approaches for the extension of a healthy lifestyle into old age, prevention of cognitive decline, as well as, development of new treatment strategies for cognitive impairment late in life.

\section{Acknowledgments}

V. Novak was supported by grants 1R01AG028076-A2 and 1P01AG028717-01A2 from the National Institute on Aging, NIH, and by grant 1R21DK084463-01A1 from the National Institute of Diabetes and Digestive and Kidney Diseases, NIH. 


\section{Reference List}

1. Pereira M, Lunet N, Azevedo A, Barros H. Differences in prevalence, awareness, treatment and control of hypertension between developing and developed countries. J Hypertens. 2009; 27:963975. [PubMed: 19402221] Distribution and impact of hypertension worldwide.

2. Rutan GH, Hermanson B, Bild DE, Kittner SJ, LaBaw F, Tell GS. Orthostatic hypotension in older adults. The Cardiovascular Health Study. CHS Collaborative Research Group. Hypertension. 1992; 19:508-519. [PubMed: 1592445]

3. Wild S, Roglic G, Green A, Sicree R, King H. Global prevalence of diabetes: estimates for the year 2000 and projections for 2030. Diabetes Care. 2004; 27:1047-1053. [PubMed: 15111519]

4. Whiting DR, Guariguata L, Weil C, Shaw J. IDF diabetes atlas: global estimates of the prevalence of diabetes for 2011 and 2030. Diabetes Res Clin Pract. 2011; 94:311-321. [PubMed: 22079683]

5. Kearney PM, Whelton M, Reynolds K, Muntner P, Whelton PK, He J. Global burden of hypertension: analysis of worldwide data. Lancet. 2005; 365:217-223. [PubMed: 15652604]

6. Novak V, Hajjar I. The relationship between blood pressure and cognitive function. Nat Rev Cardiol. 2010; 7:686-698. [PubMed: 20978471]

7. Qiu C, Winblad B, Fratiglioni L. Low diastolic pressure and risk of dementia in very old people: a longitudinal study. Dement Geriatr Cogn Disord. 2009; 28:213-219. [PubMed: 19752556]

8. Qiu C, Winblad B, Fratiglioni L. The age-dependent relation of blood pressure to cognitive function and dementia. Lancet Neurol. 2005; 4:487-499. [PubMed: 16033691]

9. Moretti R, Torre P, Antonello RM, Manganaro D, Vilotti C, Pizzolato G. Risk factors for vascular dementia: hypotension as a key point. Vasc Health Risk Manag. 2008; 4:395-402. [PubMed: 18561514]

10. Rose KM, Couper D, Eigenbrodt ML, Mosley TH, Sharrett AR, Gottesman RF. Orthostatic hypotension and cognitive function: the Atherosclerosis Risk in Communities Study. Neuroepidemiology. 2010; 34:1-7. [PubMed: 19893322]

11. Lavi S, Gaitini D, Milloul V, Jacob G. Impaired cerebral CO2 vasoreactivity: association with endothelial dysfunction. Am J Physiol Heart Circ Physiol. 2006; 291:H1856-H1861. [PubMed: 16766649]

12. Zhang P, Huang G, Shi X. Cerebral vasoreactivity during hypercapnia is reset by augmented sympathetic influence. J Appl Physiol. 2011; 110:352-358. [PubMed: 21071587]

13. Pineiro R, Matthews PM. Cerebral vasoreactivity and functional response in stroke: a study with functional MR. Rev Neurol. 2001; 33:701-708. [PubMed: 11784962]

14. Ito H, Kanno I, Takahashi K, Ibaraki M, Miura S. Regional distribution of human cerebral vascular mean transit time measured by positron emission tomography. NeuroImage. 2003; 19:1163-1169. [PubMed: 12880841]

15. Girouard H, Iadecola C. Neurovascular coupling in the normal brain and in hypertension, stroke, and Alzheimer disease. J Appl Physiol. 2006; 100:328-335. [PubMed: 16357086]

16. Aaslid R, Newell DW, Stooss R, Sorteberg W, Lindegaard K. Assessment of cerebral autoregulation dynamics from simultaneous arterial and venous transcranial Doppler recordings in humans. Stroke. 1991; 22:1148-1154. [PubMed: 1926257]

17. Aaslid, R. Cerebral Hemodynamics. In: Newell, DW.; Aaslid, R., editors. Transcranial Doppler. New York: Raven Press; 1992. p. 49-55.

18. Cigada M, Marzorati S, Tredici S, Lapichino G. Cerebral $\mathrm{CO}_{2}$ vasoreactivity by transcranial Doppler ultrasound technique a standardized methodlogy. Intensive Care Medicine. 2000; 26:729732. [PubMed: 10945390]

19. Panerai RB. Assessment of cerebral pressure autoregulation in humans--a review of measurement methods. Physiological Measurements. 1998; 19:305-3008.

20. Tiecks FP, Douville C, Byrd S, Lam AM, Newell DW. Evaluation of impaired cerebral autoregulation by the Valsalva maneuver. Stroke. 1996; 27:1177-1182. [PubMed: 8685924]

21. Panerai RB, Dawson SL, Potter JF. Linear and nonlinear analysis of human dynamic autoregulation. Am J Physiol (Heart Circ Physiol). 1999; 277:H1089-H1099.

22. Panerai RB, Eames PJ, Potter JF. Multiple coherence of cerebral blood flow velocity in humans. Am J Physiol Heart Circ Physiol. 2006; 291:H251-H259. [PubMed: 16489099] 
23. Panerai RB, Rennie JM, Kelsall AW, Evans DH. Frequency-domain analysis of cerebral autoregulation from spontaneous fluctuations in arterial blood pressure. Med Biol Eng Comput. 1998; 36:315-322. [PubMed: 9747571]

24. Low PA, Novak V, Spies JM, Novak P, Petty G. Cerebrovascular regulation in the postural tachycardia syndrome (POTS). Am J Med Sciences. 1999; 317:124-133.

25. Aaslid R, Lindegaard KF, Sorteberg W, Nornes H. Cerebral autoregulation dynamics in humans. Stroke. 1989; 20:45-52. [PubMed: 2492126]

26. Novak V, Novak P, Spies JM, Low PA. Autoregulation of cerebral blood flow in orthostatic hypotension. Stroke. 1998; 29:104-111. [PubMed: 9445337]

27. Hu K, Peng CK, Huang NE, Wu Z, Lipsitz LA, Cavallerano JD. Altered phase interactions between spontaneous blood pressure and flow fluctuations in type 2 diabetes mellitus:Nonlinear assessment of autoregulation. Physica A. 2008; 387:2279-2292. [PubMed: 18432311]

28. Eames PJ, Blake MJ, Dawson SL, Panerai RB, Potter J. Dynamic cerebral autoregulation and beatto-beat blood pressure control are impaired in acute ischaemic stroke. J Neurol Neurosurg Psychiatry. 2002; 72:467-473. [PubMed: 11909905]

29. Novak V, Chowdhary A, Farrar B, Nagaraja H, Braun J, Kanard R, Novak P, Slivka A. Altered cerebral vasoregulation in hypertension and stroke. Neurology. 2003; 60:1657-1663. [PubMed: 12771258]

30. Anonymous. Consensus statement on the definition of orthostatic hypotension, pure autonomic failure, and multiple system atrophy. 1997:1470.

31. Zhang R, Zuckerman JH, Giller CA, Levine BD. Transfer function analysis of dynamic cerebral autoregulation in humans. Am J Physiol. 1998; 274:H233-H241. [PubMed: 9458872]

32. Tiecks FP, Lam AM, Matta BF, Strebel S, Douville C, Newell DW. Effects of the Valsalva maneuver on cerebral circulation in healthy adults. A transcranial Doppler Study. Stroke. 1995; 26:1386-1392. [PubMed: 7631342]

33. Novak V, Hu K, Desrochers L, Novak P, Caplan L, Lipsitz LA, Selim M. Cerebral flow velocities during daily activities depend on blood pressure in patients with chronic ischemic infarctions. Stroke. 2010; 41:61-66. [PubMed: 19959536]

34. van Lieshout JJ, Wieling W. Perfusion of the human brain: a matter of interactions. J Physiol. 2003; 551:402. [PubMed: 12867571]

35. Davidson E, Rotenbeg Z, Fuchs J, Weinberger I, Agmon J. Transient ischemic attack-related syncope. Clinical Cardiology. 1991; 14:141-144. [PubMed: 2044243]

36. Lundberg N. Continuous recording and control of verntricular fluid pressure in neurosurgical practice. Acta Psychiatrica Scandinavica. 1960; 36:1-193. [PubMed: 13764297]

37. Maeda, M.; Takahashi, K.; Miyazaki, M.; Ishii, S. The role of the central monoamine system and the cholinoceptive pontine area on the oscillation of ICP "pressure waves". In: Miller, JD.;

Teasdale, GM.; Rowan, JO.; Galbraith, SL.; Mendelow, AD., editors. Intracranial Pressure VI. Proceedings of the Sixth International Symposium on Intracranial Pressure, glasgow; June 9-13, 1985; Scotland. Berlin: Springer-Verlag; 1986. p. 151-155.

38. Steinmeier R, Bauhuf C, Hubner U, Dietrich Bauer R, Fahlbusch R, Laumer R, Bondar I. Slow rhythmic oscillations in blood pressure, intracranial pressure, microcirculation, and cerebral oxygenation. Stroke. 1996; 27:2236-2243. [PubMed: 8969787]

39. Latka M, Turalska M, Glaubic-Latka M, Kolodziej W, Latka D, West BJ. Phase dynamics in cerebral autoregulation. Am J Physiol Heart Circ Physiol. 2005; 289:H2272-H2279. [PubMed: 16024579]

40. Hu K, Peng CK, Czosnyka M, Zhao P, Novak V. Nonlinear assessment of cerebral autoregulation from spontaneous blood pressure and cerebral blood flow fluctuations. Cardiovasc Eng. 2008; 8:60-71. [PubMed: 18080758]

41. Blaber AP, Bondar RL, Stein F, Dunphy PT, Moradshahi P, Kassam MS, Freeman R. Transfer function analysis of cerebral autoregulation dynamics in autonomic failure patients. Stroke. 1997; 28:1686-1692. [PubMed: 9303010]

42. Schondorf R, Stein R, Roberts R, Benoit J, Cupples WA. Dynamic cerebral autoregulation is preserved in neurally mediated syncope. J Appl Physiol. 2001; 91:2493-2502. [PubMed: 11717210] 
43. Czosnyka M, Piechnik S, Richards HK, Kirkpatrick P, Smielewski P, Pickard JD. Contribution of mathematical modelling to the interpretation of bedside tests of cerebrovascular autoregulation. Journal of Neurology, Neurosurgery \& Psychiatry. 1997; 63:721-731. [Review] [47 refs].

44. Bullock R, Mendelow AD, Bone I, Patterson J, Macleod WN, Allardice G. Cerebral blood flow and $\mathrm{CO}_{2}$ responsiveness as an indicator of collateral reserve capacity in patients with carotid artery disease. Br J Surg. 1985; 72:348-351. [PubMed: 3922463]

45. Last D, Alsop DC, Abduljalil AM, Marquis RP, de Bazelaire C, Hu K, Cavallerano J, Novak V. Global and regional effects of type 2 diabetes mellitus on brain tissue volumes and cerebral vasoreactivity. Diabetes Care. 2007; 30:1193-1199. [PubMed: 17290035]

46. Zhao P, Alsop D, Abduljail A, Selim M, Lipsitz L, Novak P, Caplan L, Hu K, Novak V. Altered vasoreactivity and peri-infarct hyperintensities affect multiple terriories in stroke. Neurology. 2009; 72:643-649. [PubMed: 19221298]

47. Brown GG, Clark C, Liu TT. Measurement of cerebral perfusion with arterial spin labeling: Part 2. Applications. J Int Neuropsychol Soc. 2007; 13:526-538. [PubMed: 17445302]

48. Dai W, Garcia D, de BC, Alsop DC. Continuous flow-driven inversion for arterial spin labeling using pulsed radio frequency and gradient fields. Magn Reson Med. 2008; 60:1488-1497. [PubMed: 19025913]

49. Dai W, Robson PM, Shankaranarayanan A, Alsop DC. Modified pulsed continuous arterial spin labeling for labeling of a single artery. Magn Reson Med. 2010; 64:975-982. [PubMed: 20665896]

50. Novak V, Zhao P, Manor B, Sejdic E, Alsop D, Abduljalil A, Roberson PK, Munshi M, Novak P. Adhesion molecules, altered vasoreactivity, and brain atrophy in type 2 diabetes. Diabetes Care. 2011; 34:2438-2441. [PubMed: 21926285]

51. Melzer TR, Watts R, Macaskill MR, Pearson JF, Rueger S, Pitcher TL, Livingston L, Graham C, Keenan R, Shankaranarayanan A, Alsop DC, rymple-Alford JC, Anderson TJ. Arterial spin labelling reveals an abnormal cerebral perfusion pattern in Parkinson's disease. Brain. 2011

52. Williams K, MacLean C. Transcranial assessment of maternal cerebral blood flow velocity in normal vs. hypertensive states. Variations with maternal posture. Journal of Reproductive Medicine. 1994; 39:685-688. [PubMed: 7807480]

53. Alsop DC, Detre JA. Reduced transit-time sensitivity in non-invasive magnetic resonance imaging of human cerebral blood flow. Journal Cerebral Blood Flow Metabolism. 1996; 16:1236-1249.

54. Ye FQ, berman KF, Ellmore T, Esposito G, van Horn JD, Yang Y, Duyn J, Smith AM, Frank JA, Weinberger DR, Mc Laughin AC. H2150 PET validation of steady-state arterial spin tagging cerebral blood flow measurements in humans. Magn Reson Med. 2000; 44:450-456. [PubMed: 10975898]

55. Hajjar I, Zhao P, Alsop D, Novak V. Hypertension and cerebral vasoreactivity: a continuous arterial spin labeling magnetic resonance imaging study. Hypertension. 2010; 56:859-864. [PubMed: 20876450]

56. Waldstein SR, Giggey PP, Thayer JF, Zonderman AB. Nonlinear relations of blood pressure to cognitive function: the Baltimore Longitudinal Study of Aging. Hypertension. 2005; 45:374-379. [PubMed: 15699446]

57. Waldstein SR, Rice SC, Thayer JF, Najjar SS, Scuteri A, Zonderman AB. Pulse pressure and pulse wave velocity are related to cognitive decline in the Baltimore Longitudinal Study of Aging. Hypertension. 2008; 51:99-104. [PubMed: 18025297]

58. Ikram MK, De Jong FJ, Van Dijk EJ, Prins ND, Hofman A, Breteler MN, De Jong PT. Retinal vessel diameters and cerebral small vessel disease: the Rotterdam Scan Study. Brain. 2006:182188. [PubMed: 16317022]

59. Vermeer SE, Prins ND, den Heijer T, Koudstaal PJ, Breteler MM. Silent brain infarcts and the risk of dementia and cognitive decline. N Engl J Med. 2003; 27:1215-1222. [PubMed: 12660385]

60. deGroot JC, de Leeuw FE, Ouderk M, Hofman A, Jolles J, Breteler MM. Cerebral white matter lesions and subjective cognitive dysfunction: the Rotterdam Scan Study. Neurology. 2001; 56:1539-1541. [PubMed: 11402112]

61. Manschot SM, Brands AM, vander Grond J, Kessels RP, Algra A, kappelle LJ, Biessels GJ. Brain magnetic resonance imaging correlates of impaired cognition in patients with type 2 diabetes. Diabetes. 2006; 55:1106-1113. [PubMed: 16567535] 
62. Meyer, JS.; Shaw, TG. Cerebral blood flow in aging. In: Albert, ML., editor. Clinical Neurology of Aging. New York: Oxford University Press; 1984. p. 178-196.

63. Dandona P, James IM, Newbury PA, Woollard ML, Beckett AG. Cerebral blood flow in diabetes mellitus: evidence of abnormal cerebrovascular reactivity. Br Med J. 1978; 29:325-326. [PubMed: 687900]

64. Appelman AP, Exalto LG, van der GY, Biessels GJ, Mali WP, Geerlings MI. White matter lesions and brain atrophy: more than shared risk factors? A systematic review. Cerebrovasc Dis. 2009; 28:227-242. [PubMed: 19571536] Discuss mechanisms underlying cerebromicrovascualr disease and relationship to regional brain atrophy.

65. deGroot JC, de Leeuw FE, Breteler MM. Cognitive correlates of cerebral white matter changes. J Neural Transm Suppl. 1998; 53:41-67. [PubMed: 9700645]

66. Kadoi Y, Hinohara H, Kunimoto F, Saito S, Ide M, Hiraoka H, Kawahara F, Goto F. Diabetic patients have an impaired cerebral vasodilatory response to hypercapnia under propofol anesthesia. Stroke. 2003; 34:2399-2403. [PubMed: 12958324]

67. Chimowitz MI, Furlan AJ, Jones SC, Sila CA, Lorig RL, Parandi L, Beck GJ. Transcranial Doppler assessment of cerebral perfusion reserve in patients with carotid occlusive disease and no evidence of cerebral infarction. Neurology. 1993; 43:353-357. [PubMed: 8437702]

68. Fulesdi B, Limburg M, Bereczki D, Kaplar M, Molnar C, Kappelmayer J, Neuwirth G, Csiba L. Cerebrovascular reactivity and reserve capacity in type II diabetes mellitus. J Diabetes Complications. 1999; 13:191-199. [PubMed: 10616858]

69. Kadoi Y, Saito S, Goto F, Fujita N. The effect of diabetes on the interrelationship between jugular venous oxygen saturation responsiveness to phenylephrine infusion and cerebrovascular carbon dioxide reactivity. Anesth Analg. 2004; 99:325-331. [PubMed: 15271699]

70. Griffith DN, Saimbi S, Lewis C, Tolfree S, Betteridge DJ. Abnormal cerebrovascular carbon dioxide reactivity in people with diabetes. Diabet Med. 1987; 4:217-220. [PubMed: 2956022]

71. Hidasi E, Kaplar M, Dioszeghy P, Bereczki D, Csiba L, Limburg B. No correlation between impairment of cerebrovascular reserve capacity and electrophysiologically assessed severity of neuropathy in noninsulin-dependent diabetes mellitus. J Diabetes Complications. 2002; 16:228234. [PubMed: 12015193]

72. Tkac I, Troscak M, Javorsky M, Petrik R, Tomcova M. Increased intracranial arterial resistance in patients with type 2 diabetes mellitus. Wien Klin Wochenschr. 2001; 113:870-873. [PubMed: 11762124]

73. Christoforidis GA, Bourekas E, Baujan M, Abduljalil A, Kangarlu A, Spigos D, Chakeres DM, Robitaille PML. High resolution MRI of the deep brain vascular anatomy at 8 Tesla, Susceptibility-based enhancement of the venous structures. J Comp Assist Tomogr. 1999:857866.

74. Novak V, Kangarlu A, Abduljalil A, Novak P, Slivka A, Chakeres D, Robittaille PM. Ultra High Field MRI of Subacute Hemorrhagic Stroke at 8 Tesla. J Comp Assist Tomogr. 2001; 25:431-435.

75. Novak V, Abduljalil AM, Novak P, Robitaille PM. High resolution ultra high field MRI of stroke. Magn Reson Imaging. 2005; 23:539-548. [PubMed: 15919599]

76. Whitaker CDS, Schmalbrock P, Dansher RA, Beversdorf DQ, Santi MS, Abduljalil AM, Truong TK, Chakeres DW, Scharre DW. Ultra-high field magnetic resonance imaging signal intensity change in Alzheimer's disease. 2001:323.15.

77. Novak, V.; Christiforidis, G. Clinical Promise. In: Robitaille, PM.; Berliner, LJ., editors. Ultra high field magnetic resonance imaging (UHFMRI): Theory and applications, biological magnetic resonance. A series of contemporary topics and reviews. New York: Springer; 2006. p. 411-437.

78. Kario K, Ishikawa J, HOshide S, Matsui Y, Morinari M, Eguchi K, Ishikawa S, Shimada K. Diabetic brain damage in hypertension: role of renin-angiotensin system. Hypertension. 2005; 45:887-983. [PubMed: 15824198]

79. Marstrand JR, Garde E, Rostrup E, Ring P, Rosenbaum S, Mortensen EL, Larsson HB. Cerebral perfusion and cerebrovascular reactivity are reduced in white matter hyperintensities. Stroke. 2002; 34:972-976. [PubMed: 11935046] 
80. DeCarli C, et al. The effect of white matter hyperintensity volume on brain structure, cognitive performance, and cerebral metabolism of glucose in 51 healthy adults. Neurology. 1995; 45:20772084. [PubMed: 7501162]

81. Mehagnoul-Schipper DJ, Colier WN, Jansen RW. Reproducibility of orthostatic changes in cerebral oxygenation in healthy subjects aged 70 years and older. Clin Physiol. 2001; 21:77-84. [PubMed: 11168300]

82. Novak V, Last D, Alsop DC, Abduljalil AM, Hu K, Lepicovsky L, Cavallerano J, Lipsitz LA. Cerebral blood flow velocity and periventricular white matter hyperintensities in type 2 diabetes. Diabetes Care. 2006; 29:1529-1534. [PubMed: 16801574]

83. Enzinger C, Fazekas F, Ropele S, Schmidt R. Progression of cerebral white matter lesions -clinical and radiological considerations. J Neurol Sci. 2007; 257:5-10. [PubMed: 17321549]

84. Van Raamt RF, Appelman AP, Mali WP, Van der Graaf Y. SMART Study Group. Arterial blood flow to the brain in patients with vascular disease: the SMART Study. Radiology. 2006; 240:515521. [PubMed: 16864675]

85. Xu WL, Qiu CX, Wahlin A, Winblad B, Fratiglioni L. Diabetes mellitus and risk of dementia in the Kungsholmen project: a 6-year follow-up study. Neurology. 2004; 63:1181-1186. [PubMed: 15477535]

86. Vermeer SE, Hollander M, Van Dijk EJ, Hofman A, Koudstaal PJ, Breteler MM. Silent brain infarcts and white matter lesions increase stroke risk in the general population: The Rotterdam scan study. Stroke. 2003; 34:1126-1129. [PubMed: 12690219]

87. Jokinen H, Kalska H, Ylikoski R, Madureira S, Verdelho A, Gouw A, Scheltens P, Barkhof F, Visser MC, Fazekas F, Schmidt R, O'Brien J, Hennerici M, Baezner H, Waldemar G, Wallin A, Chabriat H, Pantoni L, Inzitari D, Erkinjuntti T. MRI-defined subcortical ischemic vascular disease: baseline clinical and neuropsychological findings. The LADIS Study. Cerebrovasc Dis. 2009; 27:336-344. [PubMed: 19218799]

88. Sachdev PS, Chen X, Joscelyne A, Wen W, Brodaty H. Amygdala in stroke/transient ischemic attack patients and its relationship to cognitive impairment and psychopathology: the Sydney Stroke Study. Am J Geriatr Psychiatry. 2007; 15:487-496. [PubMed: 17545449]

89. Guo X, Pantoni L, Simoni M, Bengtsson C, Bjorkelund C, Lissner L, Gustafson D, Skoog I. Blood pressure components and changes in relation to white matter lesions: a 32-year prospective population study. Hypertension. 2009; 54:57-62. [PubMed: 19487586]

90. van Swieten JC, van den Hout JH, van Ketel BA, Hijdra A, van Gijn J. Periventricular lesions in the white matter on magnetic resonance imaging in the elderly. A morphometric correlation with arteriolosclerosis and dilated perivascular spaces. Brain. 1991; 114:761-774. [PubMed: 2043948]

91. Gouw AA, Seewann A, van der Flier WM, Barkhof F, Rozemuller AM, Scheltens P, Geurts JJ. Heterogeneity of small vessel disease: a systematic review of MRI and histopathology correlations. J Neurol Neurosurg Psychiatry. 2011; 82:126-135. [PubMed: 20935330]

92. Gouw AA, Seewann A, Vrenken H, van der Flier WM, Rozemuller JM, Barkhof F, Scheltens P, Geurts JJ. Heterogeneity of white matter hyperintensities in Alzheimer's disease: post-mortem quantitative MRI and neuropathology. Brain. 2008; 131:3286-3298. [PubMed: 18927145]

93. Gouw AA, van der Flier WM, Pantoni L, Inzitari D, Erkinjuntti T, Wahlund LO, Waldemar G, Schmidt R, Fazekas F, Scheltens P, Barkhof F. On the etiology of incident brain lacunes: longitudinal observations from the LADIS study. Stroke. 2008; 39:3083-3085. [PubMed: 18703801]

94. Wahlund LO, Barkhof F, Fazekas F, Bronge L, Augustin M, Sjogren M, Wallin A, Ader H, Leys D, Pantoni L, Pasquier F, Erkinjuntti T, Scheltens P. A new rating scale for age-related white matter changes applicable to MRI and CT. Stroke. 2001; 32:1318-1322. [PubMed: 11387493]

95. Yang Y, Hill JW, Rosenberg GA. Multiple roles of metalloproteinases in neurological disorders. Prog Mol Biol Transl Sci. 2011; 99:241-263. [PubMed: 21238938]

96. Enzinger C, Fazekas F, Matthews PM, Ropele S, Schmidt H, Smith S, Schmidt R. Risk factors for progression of brain atrophy in aging: six-year follow-up of normal subjects. Neurology. 2005; 64:1704-1711. [PubMed: 15911795] 
97. Guralnik JM, et al. A short physical performance battery assessing lower extremity function: association with self-reported disability and prediction of mortality and nursing home admission. $\mathbf{J}$ Gerontol. 1994; 49:M85-M94. [PubMed: 8126356]

98. Staessen JA, Richart T, Birkenhager WH. Less atherosclerosis and lower blood pressure for a meaningful life perspective with more brain. Hypertension. 2007; 49:389-400. [PubMed: 17283254]

99. Alsop DC, Dai W, Grossman M, Detre JA. Arterial spin labeling blood flow MRI: its role in the early characterization of Alzheimer's disease. J Alzheimers Dis. 2010; 20:871-880. [PubMed: 20413865]

100. Candelario-Jalil E, Thompson J, Taheri S, Grossetete M, Adair JC, Edmonds E, Prestopnik J, Wills J, Rosenberg GA. Matrix metalloproteinases are associated with increased blood-brain barrier opening in vascular cognitive impairment. Stroke. 2011; 42:1345-1350. [PubMed: 21454822]

101. Razay G, Vreugdenhil A, Wilcock G. Obesity, abdominal obesity and Alzheimer disease. Dement Geriatr Cogn Disord. 2006; 22:173-176. [PubMed: 16847377]

102. Richard E, Gouw AA, Scheltens P, van Gool WA. Vascular care in patients with Alzheimer disease with cerebrovascular lesions slows progression of white matter lesions on MRI: the evaluation of vascular care in Alzheimer's disease (EVA) study. Stroke. 2010; 41:554-556. [PubMed: 20056923]

103. Vanhanen M, Koivisto K, Moilanen L, Helkala EL, Hanninen T, Soininen H, Kervinen K, Kesaniemi YA, Laakso M, Kuusisto J. Association of metabolic syndrome with Alzheimer disease: a population-based study. Neurology. 2006; 67:843-847. [PubMed: 16966548]

104. Bell RD, Winkler EA, Singh I, Sagare AP, Deane R, Wu Z, Holtzman DM, Betsholtz C, Armulik A, Sallstrom J, Berk BC, Zlokovic BV. Apolipoprotein E controls cerebrovascular integrity via cyclophilin A. Nature. 2012; 485:512-516. [PubMed: 22622580]

105. Bouchard P, Ghitescu LD, Bendayan M. Morpho-functional studies of the blood-brain barrier in streptozotocin-induced diabetic rats. Diabetologia. 2002; 45:1017-1025. [PubMed: 12136401]

106. Tomassoni D, Bellagamba G, Postacchini D, Venarucci D, Amenta F. Cerebrovascular and brain microanatomy in spontaneously hypertensive rats with streptozotocin-induced diabetes. Clin Exp Hypertens. 2004; 26:305-321. [PubMed: 15195686]

107. Li W, Prakash R, Kelly-Cobbs AI, Ogbi S, Kozak A, El-Remessy AB, Schreihofer DA, Fagan SC, Ergul A. Adaptive cerebral neovascularization in a model of type 2 diabetes: relevance to focal cerebral ischemia. Diabetes. 2010; 59:228-235. [PubMed: 19808897]

108. Li W, Kelly-Cobbs AI, Mezzetti EM, Fagan SC, Ergul A. Endothelin-1-mediated cerebrovascular remodeling is not associated with increased ischemic brain injury in diabetes. Can J Physiol Pharmacol. 2010; 88:788-795. [PubMed: 20725136]

109. Yu T, Robotham JL, Yoon Y. Increased production of reactive oxygen species in hyperglycemic conditions requires dynamic change of mitochondrial morphology. Proc Natl Acad of Sci. 2006; 21:2653-2658. [PubMed: 16477035]

110. MOnnier L, Mas E, Ginet C, Michel F, Villon L, Cristol JP, Colette C. Activation of oxidative stress by acute glucose fluctuations compared with sustained chronic hyperglycemia in patients with type 2 diabetes. JAMA. 2006; 295:1681-1687. [PubMed: 16609090]

111. Kim JA, Montagnani M, Koh KK, Quon MJ. Reciprocal relationships between insulin resistance and endothelial dysfunction: molecular and pathophysiological mechanisms. Circulation. 2006; 113:1888-1904. [PubMed: 16618833]

112. Kevil CG, Orr AW, Langston W, Mickett K, Murphy-Ullrich J, Patel RP, Kucik DF, Bullard DC. Intercellular adhesion molecule-1 (ICAM-1) regulates endothelial cell motility through a nitric oxide-dependent pathway. J Biol Chem. 2004; 279:19230-19238. [PubMed: 14985356]

113. Kevil CG, Pruitt H, Kavanagh TJ, Wilkerson J, Farin F, Moellering D, rley-Usmar VM, Bullard DC, Patel RP. Regulation of endothelial glutathione by ICAM-1: implications for inflammation. FASEB J. 2004; 18:1321-1323. [PubMed: 15180961]

114. Koch AE, Hallorank MM, Haskell CJ, Shah M, Polverini PJ. Angiogenesis mediated by soluble forms of E-selectin and vascular cell adhesion molecule-1. Nature. 1995; 376:517-519. [PubMed: 7543654] 
115. Heikkila O, Lundbom N, Timonen M, Groop PH, Heikkinen S, Makimattila S. Hyperglycaemia is associated with changes in the regional concentrations of glucose and myo-inositol within the brain. Diabetologia. 2009; 52:534-540. [PubMed: 19096823]

116. Makimattila S, Malmberg-Ceder K, Hakkinen AM, Vuori K, Salonen O, Summanen P, YkiJarvinen H, Kaste M, Heikkinen S, Lundbom N, Roine RO. Brain metabolic alterations in patients with type 1 diabetes-hyperglycemia-induced injury. J Cereb Blood Flow Metab. 2004; 24:1393-1399. [PubMed: 15625413]

117. Brownlee M. The pathobiology of diabetic complications. Diabetes. 2006; 54:1615-1625. [PubMed: 15919781]

118. Vazquez LA, Amado JA, garcia-Unzueta MT, Quirce R, Jimenez-Bonilla JF, Pazos F, Pesquera C, Carril JM. Decreased plasma endothelin-1 levels in asymptomatic type I diabetic patients with regional cerebral hypoperfusion assessed by Spect. J Diabetes Complications. 1999; 13:325-331. [PubMed: 10765011]

119. Keymeulen B, Jacobs A, de Metx K, de Sadeleer C, Bossuyt A, Somers G. Regional cerebral hypoperfusion in long-term type 1 (insulin-dependent) diabetic patients: relation to hypoglycaemic event. Nucl Med Commun. 1995; 16:10-16. [PubMed: 7609929]

120. Kannel WB, Kannel C, Paffenbarger RSJ, Cupples LA. Heart rate and cardiovascular mortality: The Framingham study. Am Heart J. 1987; 113:1494.

121. Gunning-Dixon FM, Raz N. The cognitive correlates of white matter abnormalities in normal aging: a quantitative review. Neuropsychology. 2000; 14:224-232. [PubMed: 10791862]

122. Katsura K, Rodriguez de Turco EB, Siesjo BK, Bazan NG. Effects of hyperglycemia and hypercapnia on lipid metabolism during complete brain ischemia. Brain Res. 2004; 1030:133140. [PubMed: 15567345]

123. Pasquier F, Boulogne A, Leys D, Fontaine P. Diabetes mellitus and dementia. Diabetes Metab. 2006; 32:403-414. [PubMed: 17110895]

124. Razay G, Williams J, King E, Smith AD, Wilcock G. Blood pressure, dementia and Alzheimer's disease: the OPTIMA longitudinal study. Dement Geriatr Cogn Disord. 2009; 28:70-74. [PubMed: 19648748]

125. Williamson JD, Miller ME, Bryan RN, Lazar RM, Coker LH, Johnson J, Cukierman T, Horowitz KR, Murray A, Launer LJ. The Action to Control Cardiovascular Risk in Diabetes Memory in Diabetes Study (ACCORD-MIND): rationale, design, and methods. Am J Cardiol. 2007; 99:112i-122i.

126. Forette F, Seux ML, Staessen JA, Thijs L, Birkenhager WH, Babarskiene MR, Babeanu S, Bossini A, Gil-Extremera B, Girerd X, Laks T, Lilov E, Moisseyev V, Tuomilehto J, Vanhanen H, Webster J, Yodfat Y, Fagard R. Prevention of dementia in randomised double-blind placebocontrolled Systolic Hypertension in Europe (Syst-Eur) trial. Lancet. 1998; 352:1347-1351. [PubMed: 9802273]

127. Forette F, Seux ML, Staessen JA, Thijs L, Babarskiene MR, Babeanu S, Bossini A, Fagard R, Gil-Extremera B, Laks T, Kobalava Z, Sarti C, Tuomilehto J, Vanhanen H, Webster J, Yodfat Y, Birkenhager WH. The prevention of dementia with antihypertensive treatment: new evidence from the Systolic Hypertension in Europe (Syst-Eur) study. Arch Intern Med. 2002; 162:20462052. [PubMed: 12374512]

128. Hanon O, Forette F. Prevention of dementia: lessons from SYST-EUR and PROGRESS. J Neurol Sci. 2004; 226:71-74. [PubMed: 15537524]

129. Lithell H, Hansson L, Skoog I, Elmfeldt D, Hofman A, Olofsson B, Trenkwalder P, Zanchetti A. The Study on COgnition and Prognosis in the Elderly (SCOPE); outcomes in patients not receiving add-on therapy after randomization. J Hypertens. 2004; 22:1605-1612. [PubMed: 15257185]

130. Lithell H, Hansson L, Skoog I, Elmfeldt D, Hofman A, Olofsson B, Trenkwalder P, Zanchetti A. The Study on Cognition and Prognosis in the Elderly (SCOPE): principal results of a randomized double-blind intervention trial. J Hypertens. 2003; 21:875-886. [PubMed: 12714861]

131. Meyer JS, Rauch G, Rauch RA, Haque A. Risk factors for cerebral hypoperfusion, mild cognitive impairment, and dementia. Neurobiology of Aging. 2000; 21:161-169. [PubMed: 10867201] 
132. Nagai M, HOshide S, Kario K. Hypertension and dementia. Am J Hypertens. 2010; 23:116-124. [PubMed: 19927134]

133. Winblad B, Palmer K, Kivipelto M, Jelic V, Fratiglioni L, Wahlund LO, Nordberg A, Backman L, Albert M, Almkvist O, Arai H, Basun H, Blennow K, de LM, DeCarli C, Erkinjuntti T, Giacobini E, Graff C, Hardy J, Jack C, Jorm A, Ritchie K, van DC, Visser P, Petersen RC. Mild cognitive impairment--beyond controversies, towards a consensus: report of the International Working Group on Mild Cognitive Impairment. J Intern Med. 2004; 256:240-246. [PubMed: 15324367]

134. Cherbuin N, Reglade-Meslin C, Kumar R, Jacomb P, Easteal S, Christensen H, Sachdev P, Anstey KJ. Risk factors of transition from normal cognition to mild cognitive disorder: the PATH through Life Study. Dement Geriatr Cogn Disord. 2009; 28:47-55. [PubMed: 19628940]

135. Beason-Held LL, Moghekar A, Zonderman AB, Kraut MA, Resnick SM. Longitudinal changes in cerebral blood flow in the older hypertensive brain. Stroke. 2007; 38:1766-1773. [PubMed: 17510458]

136. Beason-Held LL, Kraut MA, Resnick SM I. Longitudinal changes in aging brain function. Neurobiol Aging. 2008; 29:483-496. [PubMed: 17184881]

137. Beason-Held LL, Kraut MA, Resnick SM II. Temporal patterns of longitudinal change in aging brain function. Neurobiol Aging. 2008; 29:497-513. [PubMed: 17178430]

138. Wolf PA, Beiser A, Elias MF, Au R, Vasan RS, Seshadri S. Relation of obesity to cognitive function: importance of central obesity and synergistic influence of concomitant hypertension. The Framingham Heart Study. Curr Alzheimer Res. 2007; 4:111-116. [PubMed: 17430232]

139. Selim M, Jones R, Novak P, Zhao P, Novak V. The effects of body mass index on cerebral blood flow velocity. Clin Auton Res. 2008; 18:331-338. [PubMed: 18726054]

140. Knopman DS, Mosley TH, Catellier DJ, Coker LH. Fourteen-year longitudinal study of vascular risk factors, APOE genotype, and cognition: the ARIC MRI Study. Alzheimers Dement. 2009; 5:207-214. [PubMed: 19362884]

141. Beason-Held LL, Thambisetty M, Deib G, Sojkova J, Landman BA, Zonderman AB, Ferrucci L, Kraut MA, Resnick SM. Baseline cardiovascular risk predicts subsequent changes in resting brain function. Stroke. 2012; 43:1542-1547. [PubMed: 22492519] A composite cardiovascular risk factor score, as well as it individual compontenst (e.g. age, diabetes and hypertension) were predictive of brain changes and functional decline.

142. Stewart R, Xue QL, Masaki K, Petrovitch H, Ross GW, White LR, Launer LJ. Change in blood pressure and incident dementia: a 32-year prospective study. Hypertension. 2009; 54:233-240. [PubMed: 19564551]

143. Launer LJ, Hughes T, Yu B, Masaki K, Petrovitch H, Ross GW, White LR. Lowering midlife levels of systolic blood pressure as a public health strategy to reduce late-life dementia: perspective from the Honolulu Heart Program/Honolulu Asia Aging Study. Hypertension. 2010; 55:1352-1359. [PubMed: 20404223]

144. Kitagawa K, Oku N, Kimura Y, Yagita Y, Sakaguchi M, Hatazawa J, Sakoda S. Relationship between cerebral blood flow and later cognitive decline in hypertensive patients with cerebral small vessel disease. Hypertens Res. 2009; 32:816-820. [PubMed: 19575014]

145. Muller M, Van der Graaf Y, Visseren FL, Mali WP, Geerlings MI. for the SMART Study Group. Hypertension and longitudinal changes in cerebral blood flow: The SMART-MR study. Ann Neurol. 2012; 71:825-833. [PubMed: 22447734] This study has shown prospectively the relationship between reduction in cerebral blood flow and dementia.

146. Schmidt R, Scheltens P, Erkinjuntti T, Pantoni L, Markus HS, Wallin A, Barkhof F, Fazekas F. White matter lesion progression: a surrogate endpoint for trials in cerebral small-vessel disease. Neurology. 2004; 63:139-144. [PubMed: 15249623]

147. Schmidt R, Launer LJ, Nilsson LG, Pajak A, Sans S, Berger K, Breteler K, de Ridder M, Dufouil C, Fuhrer R, Giampaoli S, Hoffman A. CASCADE Consortium. Magnetic resonance imaging of the brain in diabetes: the Cardiovascular Determinants of Dementia (CASCADE) Study. Diabetes. 2004; 53:687-692. [PubMed: 14988253]

148. Looi JC, Sachdev PS. Differentiation of vascular dementia from AD on neuropsychological tests. Neurology. 1999; 53:670-678. [PubMed: 10489025] 
149. Tell GS, Lefkowitz DS, Diehr P, Elster AD. Relationship between balance and abnormalities in cerebral magnetic resonance imaging in older adults. Arch Neurol. 1998; 55:73-79. [PubMed: 9443713]

150. Whitman GT, Tang T. A prospective study of cerebral white matter abnormalities in older people with gait dysfunction. Neurology. 2001; 57:990-994. [PubMed: 11571322]

151. Skyler JS, Bergenstal R, Bonow RO, Buse J, Deedwania P, Gale EA, Howard BV, Kirkman MS, Kosiborod M, Reaven P, Sherwin RS. Intensive glycemic control and the prevention of cardiovascular events: implications of the ACCORD, ADVANCE, and VA diabetes trials: a position statement of the American Diabetes Association and a scientific statement of the American College of Cardiology Foundation and the American Heart Association. Circulation. 2009; 119:351-357. [PubMed: 19095622]

152. Havas S. The ACCORD Trial and control of blood glucose level in type 2 diabetes mellitus: time to challenge conventional wisdom. Arch Intern Med. 2009; 169:150-154. [PubMed: 19171811]

153. Radermecker RP, Philips JC, Jandrain B, Paquot N, Scheen AJ. Blood glucose control and cardiovascular disease in patients with type 2 diabetes. Results of ACCORD, ADVANCE and VA-Diabetes trials. Rev Med Liege. 2008; 63:511-518. [PubMed: 18771232]

154. Najman DM. Intensive therapy of type 2 diabetes (ACCORD trial) (OCTOBER 2008). Cleve Clin J Med. 2009; 76:83-84. [PubMed: 19188472]

155. Jimenez-Bonilla JF, Carril JM, Quirce R, Gomez-Barquin R, Amado JA, Gutierrez-Mendiguchia C. Assessment of cerebral blood flow in diabetic patients with no clinical history of neurological disease. Nucl Med Commun. 1996; 17:790-794. [PubMed: 8895906]

156. Wakisaka M, Nagamachi S, Inoue K, Morotomi Y, Nunoi K, Fujishima M. Reduced regional cerebral blood flow in aged noninsulin-dependent diabetic patients with no history of cerebrovascular disease: evaluation by $\mathrm{N}$-isopropyl-123I-p-iodoamphetamine with single-photon emission computed tomography. J Diabetes Complications. 1990; 4:170-174.

157. MacLeod KM, Gold AE, Ebmeier KP, Hepburn DA, Deary IJ, Goodwin GM, Frier BM. The effects of acute hypoglycemia on relative cerebral blood flow distribution in patients with type I (insulin-dependent) diabetes and impaired hypoglycemia awareness. Metabolism. 1996; 45:974980. [PubMed: 8769355]

158. Cranston I, Marsden P, Matyka K, Evans M, Lomas J, Sonksen P, Maisey M, Amiel SA. Regional differences in cerebral blood flow and glucose utilization in diabetic man: the effect of insulin. J Cereb Blood Flow Metab. 1998; 18:130-140. [PubMed: 9469154]

159. Musen G, Lyoo IK, Sparks CR, Weringer K, Hwang J, Ryan CM, Jimerson DC, Hennen J, Renshaw PF, Jacobson AM. Effects of type 1 diabetes on gray matter density as measured by voxel-based morphometry. Diabetes. 2006; 55:326-333. [PubMed: 16443764]

160. Adler GK, Bonyhay I, Failing H, Waring E, Dotson S, Freeman R. Antecedent hypoglycemia impairs autonomic cardiovascular function: implications for rigorous glycemic control. Diabetes. 2009; 58:360-366. [PubMed: 19056608]

161. Eigenbrodt ML, Rose KM, Couper DJ, Arnett DK, Smith R, Jones D. Orthostatic hypotension as a risk factor for stroke. The Atherosclerosis Risk in Communities (ARIC) Study, 1987-1996. Stroke. 2000; 31:2307-2313. [PubMed: 11022055]

162. Yap PL, Niti M, Yap KB, Ng TP. Orthostatic hypotension, hypotension and cognitive status: early comorbid markers of primary dementia? Dement Geriatr Cogn Disord. 2008; 26:239-246. [PubMed: 18841007]

163. Novak V, Haertle M, Zhao P, Hu K, Munshi M, Novak P, Abduljalil A, Alsop D. White matter hyperintensities and dynamics of postural control. Magnetic Resonance Imaging. 2009; 27:752759. [PubMed: 19250785]

164. Fedorowski A, Stavenow L, Hedblad B, Berglund G, Nilsson PM, Melander O. Consequences of orthostatic blood pressure variability in middle-aged men (The Malmo Preventive Project). J Hypertens. 2010; 28:551-559. [PubMed: 19952779]

165. Kahonen-Vare M, Brunni-Hakala S, Lindroos M, Pitkala K, Strandberg T, Tilvis R. Left ventricular hypertrophy and blood pressure as predictors of cognitive decline in old age. Aging Clin Exp Res. 2004; 16:147-152. [PubMed: 15195990] 
166. Romero-Ortuno R, Kenny RA. The frailty index in Europeans: association with age and mortality. Age Ageing. 2012 Apr 19. Epub.

167. Waldstein SR, Brown JR, Maier KJ, Katzel LI. Diagnosis of hypertension and high blood pressure levels negatively affect cognitive function in older adults. Ann Behav Med. 2005; 29:174-180. [PubMed: 15946111]

168. Pendlebury ST, Cuthbertson FC, Welch SJ, Mehta Z, Rothwell PM. Underestimation of cognitive impairment by mini-mental state examination versus the montreal cognitive assessment in patients with transient ischemic attack and stroke: a population-based study. Stroke. 2010; 41:1290-1293. [PubMed: 20378863]

169. Oveisgharan S, Hachinski V. Hypertension, executive dysfunction, and progression to dementia: the canadian study of health and aging. Arch Neurol. 2010; 67:187-192. [PubMed: 20142526]

170. Hajjar I, Zhao P, Alsop D, Abduljalil A, Selim M, Novak P, Novak V. Association of blood pressure elevation and nocturnal dipping with brain atrophy, perfusion and functional measures in stroke and nonstroke individuals. Am J Hypertens. 2010; 23:17-23. [PubMed: 19798036]

171. Hajjar I, Yang F, Sorond F, Jones RN, Milberg W, Cupples LA, Lipsitz LA. A novel aging phenotype of slow gait, impaired executive function, and depressive symptoms: relationship to blood pressure and other cardiovascular risks. J Gerontol A Biol Sci Med Sci. 2009; 64:9941001. [PubMed: 19535785]

172. Bejan-Angoulvant T, Saadatian-Elahi M, Wright JM, Schron EB, Lindholm LH, Fagard R, Staessen JA, Gueyffier F. Treatment of hypertension in patients 80 years and older: the lower the better? A meta-analysis of randomized controlled trials. J Hypertens. 2010; 28:1366-1372. [PubMed: 20574244]

173. Li NC, Lee A, Whitmer RA, Kivipelto M, Lawler E, Kazis LE, Wolozin B. Use of angiotensin receptor blockers and risk of dementia in a predominantly male population: prospective cohort analysis. BMJ. 2010; 340:b5465. [PubMed: 20068258]

174. Fogari R, Mugellini A, Zoppi A, Derosa G, Pasotti C, Fogari E, Preti P. Influence of losartan and atenolol on memory function in very elderly hypertensive patients. J Hum Hypertens. 2003; 17:781-785. [PubMed: 14578918]

175. Fogari R, Mugellini A, Zoppi A, Lazzari P, Destro M, Rinaldi A, Preti P. Effect of telmisartan/ hydrochlorothiazide vs lisinopril/hydrochlorothiazide combination on ambulatory blood pressure and cognitive function in elderly hypertensive patients. J Hum Hypertens. 2006; 20:177-185. [PubMed: 16306998]

176. Tedesco MA, Ratti G, Mennella S, Manzo G, Grieco M, Rainone AC, Iarussi D, Iacono A. Comparison of losartan and hydrochlorothiazide on cognitive function and quality of life in hypertensive patients. Am J Hypertens. 1999; 12:1130-1134. [PubMed: 10604491]

177. Sink KM, Leng X, Williamson J, Kritchevsky SB, Yaffe K, Kuller L, Yasar S, Atkinson H, Robbins M, Psaty B, Goff DC Jr. Angiotensin-converting enzyme inhibitors and cognitive decline in older adults with hypertension: results from the Cardiovascular Health Study. Arch Intern Med. 2009; 169:1195-1202. [PubMed: 19597068]

178. von Bohlen und HO. The renin-angiotensin system in the mammalian central nervous system. Curr Protein Pept Sci. 2005; 6:355-371. [PubMed: 16101434]

179. Benigni A, Cassis P, Remuzzi G. Angiotensin II revisited: new roles in inflammation, immunology and aging. EMBO Mol Med. 2010; 2:247-257. [PubMed: 20597104]

180. Fleegal-DeMotta MA, Doghu S, Banks WA. Angiotensin II modulates BBB permeability via activation of the AT(1) receptor in brain endothelial cells. J Cereb Blood Flow Metab. 2009; 29:640-647. [PubMed: 19127280]

181. Suzuki Y, Ruiz-Ortega M, Lorenzo O, Ruperez M, Esteban V, Egido J. Inflammation and angiotensin II. Int J Biochem Cell Biol. 2003; 35:881-900. [PubMed: 12676174]

182. Alvarez A, Cerda-Nicolas M, Naim Abu NY, Mata M, Issekutz AC, Panes J, Lobb RR, Sanz MJ. Direct evidence of leukocyte adhesion in arterioles by angiotensin II. Blood. 2004; 104:402-408. [PubMed: 15044253]

183. de GM, Catt KJ, Inagami T, Wright JW, Unger T. International union of pharmacology. XXIII. The angiotensin II receptors. Pharmacol Rev. 2000; 52:415-472. [PubMed: 10977869] 
184. Saavedra JM, Ando H, Armando I, Baiardi G, Bregonzio C, Jezova M, Zhou J. Brain angiotensin II, an important stress hormone: regulatory sites and therapeutic opportunities. Ann N Y Acad Sci. 2004; 1018:76-84. [PubMed: 15240355]

185. Saavedra JM, Benicky J. Brain and peripheral angiotensin II play a major role in stress. Stress. 2007; 10:185-193. [PubMed: 17514587]

186. Saavedra JM. Brain angiotensin II: new developments, unanswered questions and therapeutic opportunities. Cell Mol Neurobiol. 2005; 25:485-512. [PubMed: 16075377]

187. Zhou J, Ando H, Macova M, Dou J, Saavedra JM. Angiotensin II AT1 receptor blockade abolishes brain microvascular inflammation and heat shock protein responses in hypertensive rats. J Cereb Blood Flow Metab. 2005; 25:878-886. [PubMed: 15729290]

188. Seltzer A, Bregonzio C, Armando I, Baiardi G, Saavedra JM. Oral administration of an AT1 receptor antagonist prevents the central effects of angiotensin II in spontaneously hypertensive rats. Brain Res. 2004; 1028:9-18. [PubMed: 15518636]

189. Pelisch N, Hosomi N, Ueno M, Nakano D, Hitomi H, Mogi M, Shimada K, Kobori H, Horiuchi M, Sakamoto H, Matsumoto M, Kohno M, Nishiyama A. Blockade of AT1 receptors protects the blood-brain barrier and improves cognition in Dahl salt-sensitive hypertensive rats. Am J Hypertens. 2011; 24:362-368. [PubMed: 21164491]

190. Pelisch N, Hosomi N, Ueno M, Masugata H, Murao K, Hitomi H, Nakano D, Kobori H, Nishiyama A, Kohno M. Systemic candesartan reduces brain angiotensin II via downregulation of brain renin-angiotensin system. Hypertens Res. 2010; 33:161-164. [PubMed: 19942928]

191. Smeda JS, McGuire JJ. Effects of poststroke losartan versus captopril treatment on myogenic and endothelial function in the cerebrovasculature of SHRsp. Stroke. 2007; 38:1590-1596. [PubMed: 17379826]

192. Smeda JS, Daneshtalab N. The effects of poststroke captopril and losartan treatment on cerebral blood flow autoregulation in SHRsp with hemorrhagic stroke. J Cereb Blood Flow Metab. 2011; 31:476-485. [PubMed: 20648036]

193. Saavedra JM, de Oliveira AM, Johren O, Viswanathan M. Brain angiotensin II and related receptors: new developments. Adv Exp Med Biol. 1996; 396:247-252. [PubMed: 8726705]

194. Saavedra JM. Angiotensin II AT(1) Receptor Blockers Ameliorate Inflammatory Stress: A Beneficial Effect for the Treatment of Brain Disorders. Cell Mol Neurobiol. 2011

195. Saavedra JM, Benicky J, Zhou J. Angiotensin II: multitasking in the brain. J Hypertens Suppl. 2006; 24:S131-S137. [PubMed: 16601566]

196. Candido R, Allen TJ, Lassila M, Cao Z, Thallas V, Cooper ME, Jandeleit-Dahm KA. Irbesartan but not amlodipine suppresses diabetes-associated atherosclerosis. Circulation. 2004; 109:15361542. [PubMed: 15023892]

197. Barzilay JI, Gao P, O'Donnell M, Mann JF, Anderson C, Fagard R, Probstfield J, Dagenais GR, Teo K, Yusuf S. Albuminuria and decline in cognitive function: The ONTARGET/ TRANSCEND studies. Arch Intern Med. 2011; 171:142-150. [PubMed: 21263104]

198. Viberti G, Wheeldon NM. Microalbuminuria reduction with valsartan in patients with type 2 diabetes mellitus: a blood pressure-independent effect. Circulation. 2002; 106:672-678. [PubMed: 12163426]

199. Trenkwalder P. The Study on COgnition and Prognosis in the Elderly (SCOPE)--recent analyses. J Hypertens Suppl. 2006; 24:S107-S114. [PubMed: 16601563]

200. Cheung BM, Cheung GT, Lauder IJ, Lau CP, Kumana CR. Meta-analysis of large outcome trials of angiotensin receptor blockers in hypertension. J Hum Hypertens. 2006; 20:37-43. [PubMed: 16121197]

201. Pedreanez A, Arcaya JL, Carrizo E, Rincon J, Viera N, Pena C, Vargas R, Mosquera J. Experimental depression induces renal oxidative stress in rats. Physiol Behav. 2011; 104:10021009. [PubMed: 21741982]

202. Wright JW, Harding JW. The angiotensin AT4 receptor subtype as a target for the treatment of memory dysfunction associated with Alzheimer's disease. J Renin Angiotensin Aldosterone Syst. 2008; 9:226-237. [PubMed: 19126664]

203. Drake C, Boutin H, Jones MS, Denes A, McColl BW, Selvarajah JR, Hulme S, Georgiou RF, Hinz R, Gerhard A, Vail A, Prenant C, Julyan P, Maroy R, Brown G, Smigova A, Herholz K, 
Kassiou M, Crossman D, Francis S, Proctor SD, Russell JC, Hopkins SJ, Tyrrell PJ, Rothwell NJ, Allan SM. Brain inflammation is induced by co-morbidities and risk factors for stroke. Brain Behav Immun. 2011; 6:1113-1122. [PubMed: 21356305] Evidence for relationship between bran inflammation and altered vascular function in associated with co-morbidities

204. Hernandez-Fonseca JP, Rincon J, Pedreanez A, Viera N, Arcaya JL, Carrizo E, Mosquera J. Structural and ultrastructural analysis of cerebral cortex, cerebellum, and hypothalamus from diabetic rats. Exp Diabetes Res. 2009; 2009329632.

205. Sironi L, Calvio AM, Arnaboldi L, Corsini A, Parolari A, de GM, Tremoli E, Mussoni L. Effect of valsartan on angiotensin II-induced plasminogen activator inhibitor-1 biosynthesis in arterial smooth muscle cells. Hypertension. 2001; 37:961-966. [PubMed: 11244025]

206. Sironi L, Gelosa P, Guerrini U, Banfi C, Crippa V, Brioschi M, Gianazza E, Nobili E, Gianella A, de GM, Tremoli E. Anti-inflammatory effects of AT1 receptor blockade provide end-organ protection in stroke-prone rats independently from blood pressure fall. J Pharmacol Exp Ther. 2004; 311:989-995. [PubMed: 15302895]

207. Conen D, Everett BM, Glynn RJ, Ridker PM. Effect of valsartan compared with valsartan/ hydrochlorothiazide on plasma levels of cellular adhesion molecules: the Val-MARC trial. Heart. 2008; 94:e13. [PubMed: 17923463]

208. Shrikhande GV, Scali ST, da Silva CG, Damrauer SM, Csizmadia E, Putheti P, Matthey M, Arjoon R, Patel R, Siracuse JJ, Maccariello ER, Andersen ND, Monahan T, Peterson C, Essayagh S, Studer P, Guedes RP, Kocher O, Usheva A, Veves A, Kaczmarek E, Ferran C. Oglycosylation regulates ubiquitination and degradation of the anti-inflammatory protein A20 to accelerate atherosclerosis in diabetic ApoE-null mice. PLoS One. 2010; 5:e14240. [PubMed: 21151899]

209. Fogari R, Mugellini A, Zoppi A, Marasi G, Pasotti C, Poletti L, Rinaldi A, Preti P. Effects of valsartan compared with enalapril on blood pressure and cognitive function in elderly patients with essential hypertension. Eur J Clin Pharmacol. 2004; 59:863-868. [PubMed: 14747881]

210. Kjeldsen SE, Julius S, Mancia G, McInnes GT, Hua T, Weber MA, Coca A, Ekman S, Girerd X, Jamerson K, Larochelle P, MacDonald TM, Schmieder RE, Schork MA, Stolt P, Viskoper R, Widimsky J, Zanchetti A. Effects of valsartan compared to amlodipine on preventing type 2 diabetes in high-risk hypertensive patients: the VALUE trial. J Hypertens. 2006; 24:1405-1412. [PubMed: 16794491]

211. Julius S, Weber MA, Kjeldsen SE, McInnes GT, Zanchetti A, Brunner HR, Laragh J, Schork MA, Hua TA, Amerena J, Balazovjech I, Cassel G, Herczeg B, Koylan N, Magometschnigg D, Majahalme S, Martinez F, Oigman W, Seabra GR, Zhu JR. The Valsartan Antihypertensive Long-Term Use Evaluation (VALUE) trial: outcomes in patients receiving monotherapy. Hypertension. 2006; 48:385-391. [PubMed: 16864741]

212. Sever P. The VALUE trial: a commentary. J Renin Angiotensin Aldosterone Syst. 2004; 5:99101. [PubMed: 15526243]

213. de Maat MP, Kluft C, Gram J, Jespersen J. Angiotensin-converting enzyme inhibitor trandolapril does not affect C-reactive protein levels in myocardial infarction patients. Circulation. 2003; 108:e113. [PubMed: 14557351] 


\section{Cerebral autoregulation}

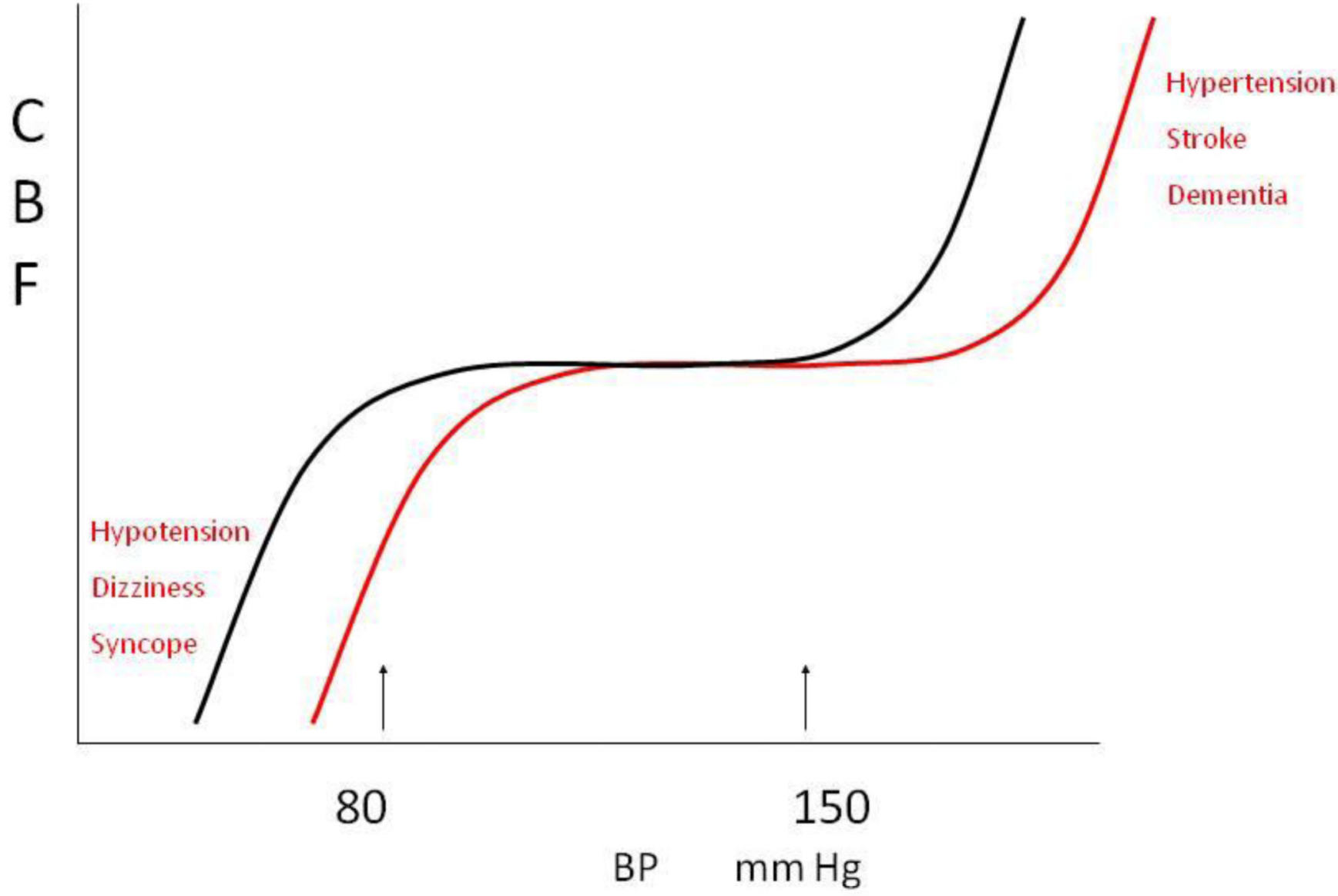

Figure 1.

Cerebral autoregulation curve- denotes the normal range of pressure -flow regulation (black line) and a right shift of the autoregulation curve toward higher BP values, associated with hypertension (red line). 

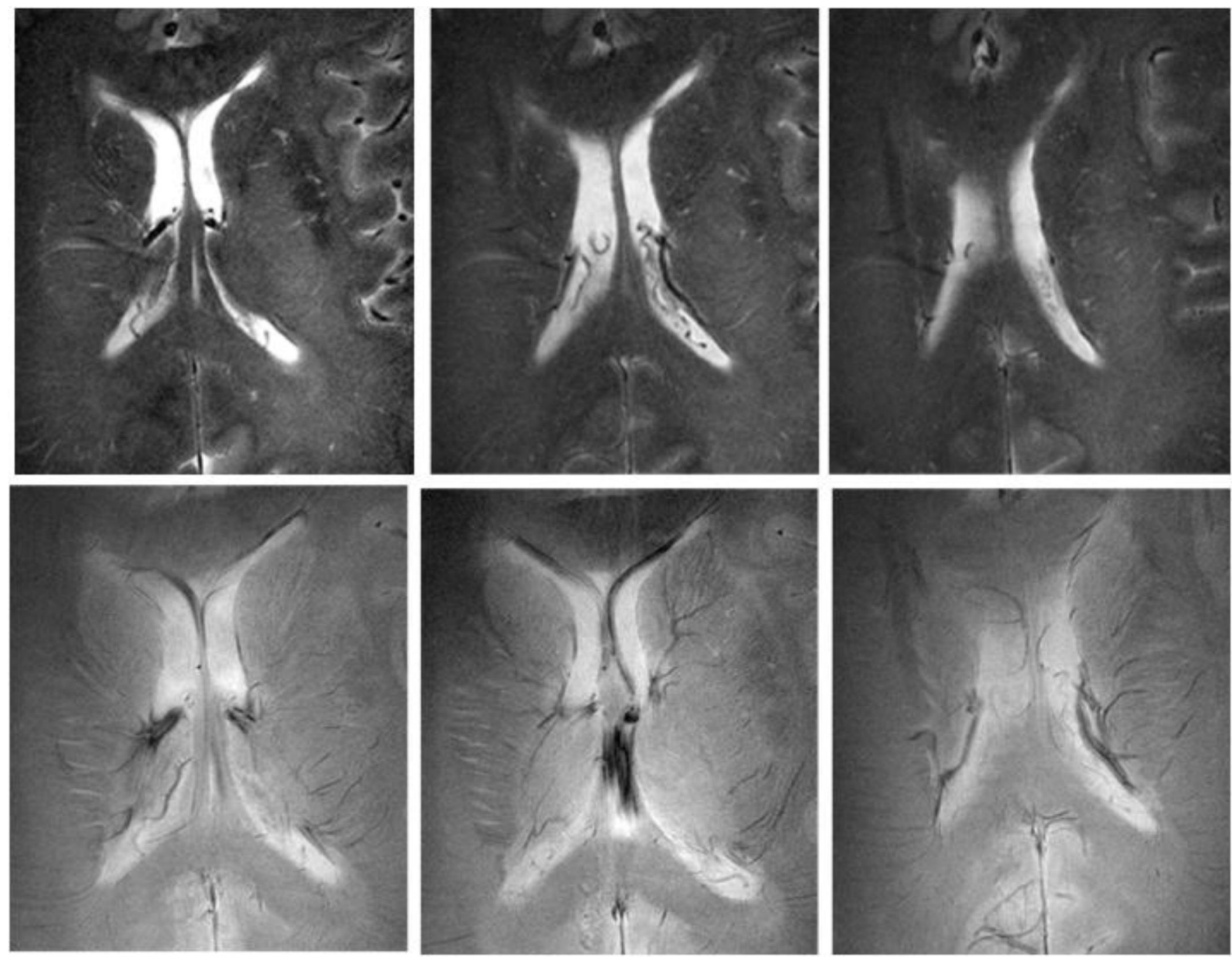

Figure 2.

High resolution anatomical images obtained using 8Tesla MRI, a 45-year-old woman with a small vessel disease. Rapid acquisition with relaxation enhancement (RARE) images (A, B, C) at the level of ventricles showed confluent white matter hyperintensities (WMHs) extending from the anterior and posterior horns of the ventricles (white arrows). Additional focal areas of high signal intensity were seen in the periventricular white matter and basal ganglia. 8T GE images (D, E, F) showed normal pattern of microvasculature as signal voids (black arrows).(GE: BW=69.4 kHz, FOV=20×20cm, slice thickness $2.3 \mathrm{~mm}, \mathrm{TR}=600 \mathrm{~ms}$, $\mathrm{TE}=10 \mathrm{~ms}$, matrix $1024 \times 1024$; RARE: $\mathrm{BW}=69.4 \mathrm{kHz}, \mathrm{FOV}=20 \times 20 \mathrm{~cm} 2$, slice thickness $2 \mathrm{~mm}, \mathrm{TR}=3000 \mathrm{~ms}, \mathrm{TE}=22 \mathrm{~ms}$, matrix $512 \times 512$, RARE factor 4). (Reproduced with permission from: Novak V, Christiforidis G: Clinical promise. In: Robitaille PM, Berliner LJ, editors. Ultra high field magnetic resonance imaging (UHFMRI): Theory and applications, biological magnetic resonance. A series of contemporary topics and reviews. (With permission from: Novak V. Clinical Promise: Clinical Imaging at Ultra High Field. 2007; 26(13): 411-437) [77]. 


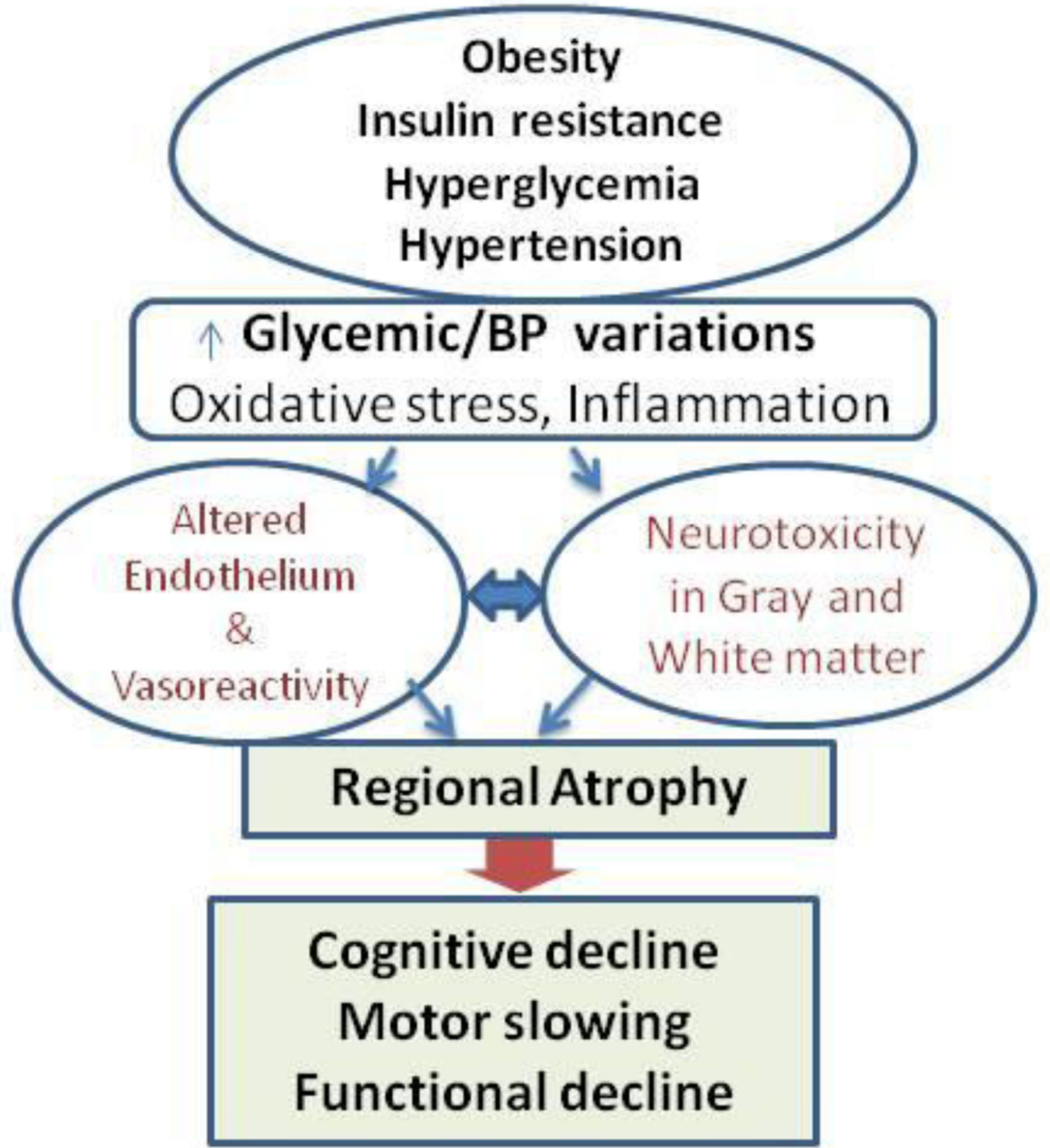

Figure 3.

A conceptual model of pathways that link cardiovascular risk factors (obesity, insulin resistance, chronic hyperglycemia and hypertension) with metabolic and autonomic dysregulation of arterial pressure and glucose, leading to increased oxidative stress and vascular inflammation. Their additive effects alter neurovascular coupling and vasoreactivity, leading to brain atrophy and functional decline. 


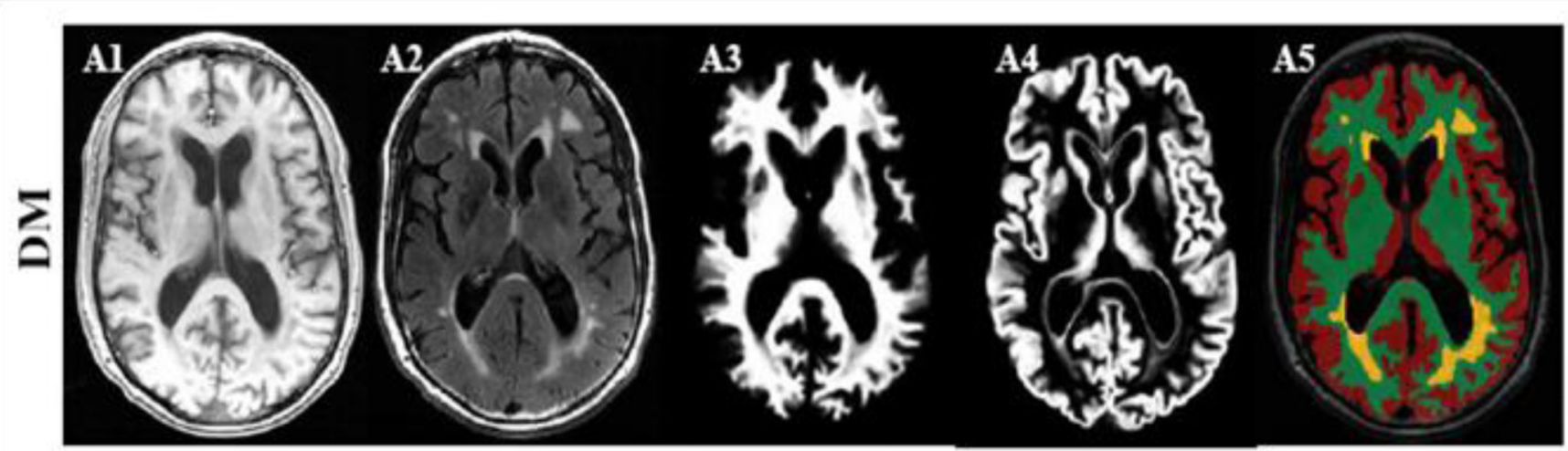

MP-RAGE

FLAIR

WM

GM

WMHs

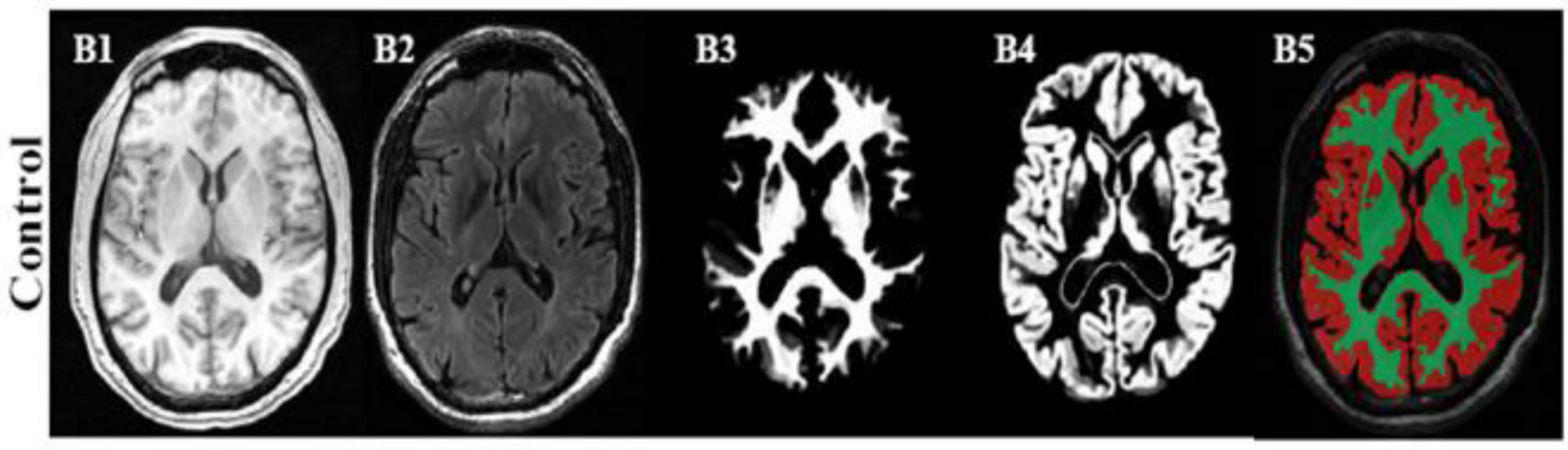

Figure 4.

Anatomical images of a diabetic (A1-A5) and a control subject (B1-B5) demonstrate that type 2 diabetes is associated with atrophy of gray (GM) and white matter (WM), enlarged ventricles) and diffuse periventricular hyperintensities (WMHs). 3D Magnetization prepared rapid gradient echo (MP_RAGE) and fluid attenuated inversion recovery (FLAIR) images were acquired at 3 Tesla MRI (MP_RAGE: $\mathrm{T}_{\mathrm{R}} / \mathrm{T}_{\mathrm{E}} / \mathrm{T}_{\mathrm{I}}=7.8 / 3.1 / 600 \mathrm{~ms}, 3.0 \mathrm{~mm}$ slice thickness, 52 slices, bandwidth $=122 \mathrm{~Hz}$ per pixel, flip angle $=10^{\circ}, 24 \mathrm{~cm} \times 24 \mathrm{~cm} \mathrm{FOV}$, $256 \times 192$ matrix size $),$ FLAIR $\left(\mathrm{T}_{\mathrm{R}} / \mathrm{T}_{\mathrm{E}} / \mathrm{T}_{\mathrm{I}}=11000 / 161 / 2250 \mathrm{~ms}, 5 \mathrm{~mm}\right.$ slice thickness, 30 slices, bandwidth $=122 \mathrm{~Hz}$ per pixel, flip angle $=90^{\circ}, 24 \mathrm{~cm} \times 24 \mathrm{~cm} \mathrm{FOV}, 256 \times 160$ matrix size). 